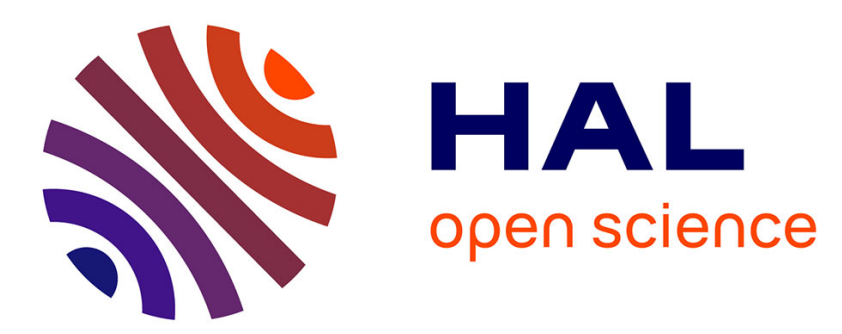

\title{
Tectonic evolution of the 'Liguride' accretionary wedge in the Cilento area; southern Italy: a record of early Apennine geodynamics
}

\author{
S. Vitale, S. Ciarcia, S. Mazzoli, M.N. Zaghloul
}

\section{> To cite this version:}

S. Vitale, S. Ciarcia, S. Mazzoli, M.N. Zaghloul. Tectonic evolution of the 'Liguride' accretionary wedge in the Cilento area; southern Italy: a record of early Apennine geodynamics. Journal of Geodynamics, 2010, 51 (1), pp.25. 10.1016/j.jog.2010.06.002 . hal-00701271

\section{HAL Id: hal-00701271 \\ https://hal.science/hal-00701271}

Submitted on 25 May 2012

HAL is a multi-disciplinary open access archive for the deposit and dissemination of scientific research documents, whether they are published or not. The documents may come from teaching and research institutions in France or abroad, or from public or private research centers.
L'archive ouverte pluridisciplinaire HAL, est destinée au dépôt et à la diffusion de documents scientifiques de niveau recherche, publiés ou non, émanant des établissements d'enseignement et de recherche français ou étrangers, des laboratoires publics ou privés. 


\section{Accepted Manuscript}

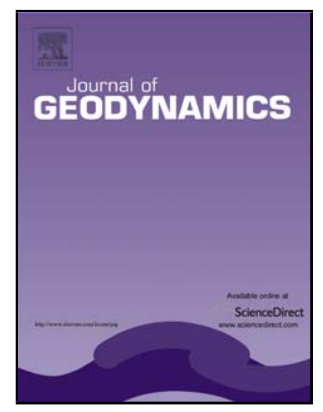

Title: Tectonic evolution of the 'Liguride' accretionary wedge in the Cilento area; southern Italy: a record of early Apennine geodynamics

Authors: S. Vitale, S. Ciarcia, S. Mazzoli, M.N. Zaghloul

PII:

S0264-3707(10)00094-3

DOI: doi:10.1016/j.jog.2010.06.002

Reference: GEOD 1010

To appear in:

$$
\text { Journal of Geodynamics }
$$

Received date: $\quad 8-1-2010$

Revised date: 25-5-2010

Accepted date: $\quad$ 6-6-2010

Please cite this article as: Vitale, S., Ciarcia, S., Mazzoli, S., Zaghloul, M.N., Tectonic evolution of the 'Liguride' accretionary wedge in the Cilento area; southern Italy: a record of early Apennine geodynamics, Journal of Geodynamics (2008), doi:10.1016/j.jog.2010.06.002

This is a PDF file of an unedited manuscript that has been accepted for publication. As a service to our customers we are providing this early version of the manuscript. The manuscript will undergo copyediting, typesetting, and review of the resulting proof before it is published in its final form. Please note that during the production process errors may be discovered which could affect the content, and all legal disclaimers that apply to the journal pertain. 
1 Tectonic evolution of the 'Liguride' accretionary wedge in the Cilento area, southern Italy: a

2 record of early Apennine geodynamics

3

4

Vitale S. ${ }^{1}{ }^{*}$, Ciarcia S. ${ }^{1}$, Mazzoli S. ${ }^{1}$, Zaghloul M.N. ${ }^{2}$

5 Dipartimento Scienze della Terra, Università di Napoli Federico II, Largo San Marcellino 10,

6 80138 Napoli, Italy

7

2 Department of Earth Sciences, University of Abdelmalek Essaadi, Tangier, M orocco

8

9 Key-words: subduction, superposed folding, synorogenic sedimentation, stratigraphic record,

10 structural analysis, Apennine Orogen

11

12

13

14

15

$16 *$ Corresponding author.

17 E-mail address: stefano.vitale@unina.it (S. Vitale)

18 
18 Abstract

19 The early stages of southern Apennine development have been unraveled by integrating the available stratigraphic record provided by synorogenic strata (of both foredeep and wedge-

21 top basin environments) with new structural data on the Liguride accretionary wedge cropping out in the Cilento area, southern Italy. Our results indicate that the final oceanic subduction stages and early deformation of the distal part of the Apulian continental margin were controlled by dominant NW-SE shortening. Early Miocene subduction-accretion, subsequent wedge emplacement on top of the Apulian continental margin and onset of footwall imbrication involving detached Apulian continental margin carbonate successions were followed by extensional deformation of the previously 'obducted' accretionary wedge. Wedge thinning also enhanced the development of accommodation space, filled by the dominantly siliciclastic Cilento Group deposits. The accretionary wedge units and the unconformably overlying wedge-top basin sediments experienced renewed NW-SE

31 shortening immediately following the deposition of the Cilento Group (reaching the early

32 Tortonian), confirming that the preceding wedge thinning represented an episode of synorogenic extension occurring within the general framework of NW-SE convergence. The documented Early to the Late M iocene steps of southern Apennine development are clearly distinct with respect to the subsequent (late Tortonian-Quaternary) stages of fold and thrust belt evolution coeval with Tyrrhenian back-arc extension, which were characterized by NE-

37 directed thrusting in the southern Apennines. 
41 The southern Apennines are part of the peri-M editerranean Alpine belt and result from the

42 interaction between the converging Apulian and European plates since Late Cretaceous time

43 (e.g. Mazzoli and Helman, 1994, and references therein). The related tectonic evolution

44 involved the subduction of Tethyan oceanic lithosphere beneath the overriding Calabrian

45 continental crust (Bonardi et al., 2001). Following Early Miocene docking of the two

46 continental margins, the subduction of oceanic lithosphere gave way to that of continental

47 lithosphere (Ranalli et al., 2000), which is also evinced by exhumed HP-LT rocks originally

48 belonging to the distal part of the Apulian continental palaeomargin (Iannace et al., 2007).

49 During the Early Miocene, the tectonic wedge formed by oceanic and transitional units

50 (Liguride Units; Bonardi et al., 1988; 'Internal' Units, Ciarcia et al., 2009; Vitale et al., 2010)

51 overthrusted the inner sector of the Apennine Platform (M ostardini and Merlini, 1986; Fig.

52 1). Subsequently, detached Mesozoic-Neogene sedimentary successions of the foreland (i.e.

53 Apulian) plate were piled up eastward onto progressively outer domains, while

54 sedimentation was occurring in both wedge-top and foredeep basins (Bonardi et al., 2009).

55 Remnants of the oldest part of the Apennine accretionary wedge, represented by the

56 Liguride Units and associated M iocene wedge-top basin deposits, crop out extensively in the

57 southern Apennines (Fig. 1). The aim of this paper is to analyze the structural setting and the

58 tectonic evolution of the Liguride accretionary wedge, in order to investigate the first steps

59 of the Apennine orogeny. A complete structural analysis is provided for the Liguride Units

60 and associated wedge-top basin successions cropping out in Cilento (Fig. 1).

61

62

\section{2. Geological setting}

63 
64 The Liguride Units of the southern Apennines (Fig. 2) encompass the ophiolite-bearing Frido

65

66

67

68

69

70 and Nord-Calabrese units (Bonardi et al., 1988, 2001) as well as the Parasicilide and Sicilide units (Ciarcia et al., 2009; Vitale et al., 2010, and references therein), the latter two including basin successions probably deposited on thinned continental/transitional crust. Starting from the Early Miocene, all of these units were deformed and accreted into the Apennine tectonic wedge (Ciarcia et al., 2009; Vitale et al., 2010) and then unconformably overlain by wedge-top basin deposits of the Cilento Group (Amore et al., 1988) and Monte Pruno Fm (Ciarcia et al., 2009). In the Cilento, only the Parasicilide and Nord-Calabrese units crop out (Fig. 3a). The 'Internal' Units (i.e. the Liguride Units) tectonically overlie the 'External' Units that were derived from the deformation of sedimentary cover successions belonging to the Apulian continental margin (Fig. 3a). These comprise shallow-water and slope carbonates (Apennine Platform) and pelagic basin (Lagonegro Basin) successions (e.g. Mazzoli et al., 2008, and references therein). Lower-Middle and Upper M iocene wedge-top basin deposits occur on top of the tectonic pile (Fig. 2).

The Nord-Calabrese Unit includes Jurassic pillow lavas at the base, overlain by the Timpa delle Murge Fm (consisting of argillites, quartz-arenites, limestones and jaspers) and then by the Crete Nere and Saraceno fms. In the Cilento area, only the latter two formations occur. The Crete Nere and Saraceno fms (Fig. 4) comprise a predominately siliciclastic and calciclastic succession deposited on oceanic crust (Bonardi et al., 1988) during plate convergence. The Crete Nere Fm is formed, from bottom to top, by a thick succession of black shales with intercalation of arenites, dark-brownish argillites and arenites in the middle part, and calcareous beds in the upper part. The middle-upper part of this formation has been dated as Middle Eocene; however the undated lower part could be as old as Late Jurassic, as suggested by Bonardi et al. (1988). The Crete Nere Fm stratigraphically passes 
88 upwards to the Saraceno Fm, which is characterized by calciclastic, locally silicified turbidites

89 (Punta Telegrafo M ember) at the base, followed by marls, pelites and arenites in the middle

90 part and finally by sandstones of the Sovereto Member (Bonardi et al., 2009). The

91 uppermost part of the Saraceno Fm has been dated as Aquitanian-Burdigalian (Bonardi et

92 al., 2009).

93 The Parasicilide Unit (Bonardi et al., 2004; Ciarcia et al., 2009; Vitale et al., 2010) cropping

94 out in Cilento and corresponding to the Castelnuovo Cilento Unit of Cammarosano et al.

95 (2000, 2004), comprises both pre-orogenic and foredeep basin deposits (Fig. 4) grouped into

96 four formations (from bottom to top): (i) micaceous sandstones, varicolored clays and slates

97 of the Postiglione Fm; (ii) marls and limestones of the Monte Sant'Arcangelo Fm; (iii) whitish

98 marls and marly limestones of the Contursi Fm; and (iv) foredeep sandstones of the Arenarie

99 di Albanella Fm (Donzelli and Crescenti, 1962). Due to intense folding, the original thickness

100 of the whole succession can only be approximately estimated as exceeding 800-1000

101 meters. The dated portions of the succession range in age between Middle Eocene and

102 Burdigalian; however, the lower undated deposits could be as old as Late Cretaceous

103 (Bonardi et al., 1988; Guerrera et al., 2005).

104 The Cilento Group, whose age ranges from the Burdigalian/Langhian boundary (Amore et

105 al., 1988) to the lower Tortonian (Russo et al., 1995), is formed by arenitic and marly

106 deposits (Fig. 4) of the Pollica and San Mauro fms (letto et al., 1965) laterally passing

107 southward to conglomeratic, arenitic and marly deposits of the Torrente Bruca Fm (Amore et

108 al., 1988). The Pollica Fm is formed by a thin-bedded succession of sandstones and pelites in

109 the lower part (Cannicchio Sandstones Member), passing to a thin- to medium-bedded

110 succession of sandstones, conglomerates, marls and pelites in the middle-upper part. The

111 overlying San Mauro Fm is characterized by a medium- to thick-bedded succession of marls 
112 and conglomerates. In the Lucania region, to the east, these formations correspond to the

113 undifferentiated succession of the Albidona Fm (Selli, 1962). These deposits and the

114 underlying units are covered unconformably by younger (Upper Miocene) coarse-grained

115 wedge-top basin successions including: (i) the Castelvetere Fm (Pescatore et al., 1970), (ii)

116 the Monte Sacro Fm (Selli, 1962), and (iii) the Oriolo (Selli, 1962), Serra Manganile (Ghezzi

117 and Bayliss, 1964) and Gorgoglione (Selli, 1962) Fms, cropping out in the Sele River Valley,

118 Cilento and Lucania, respectively (Figs. 1, 2, 3a, 4).

119 The Nord-Calabrese Unit is generally tectonically superposed onto the Parasicilide Unit (e.g.

120 Alento and Lambro River Valleys, Fig. 3a). However, in the Sapri area it lies directly over the

121 carbonates of the Apennine Platform, whereas northeastward of Cicerale-Monte

122 Centaurino, this unit does not crop out (e.g. Torrente Pietra and Sele River Valleys Fig. 3a).

123 The Cilento Group unconformably covers the already deformed and imbricated Nord-

124 Calabrese and Parasicilide units. This feature is shown in the geological map (Fig. 3a) and in

125 cross section X-X' (Fig. 3b): the Cilento Group seals the Crete Nere and Saraceno fms (Nord-

126 Calabrese Unit) in the Alento River Valley, west of the Lambro River and in the Sapri area,

127 whereas it covers the Parasicilide Unit (located in the footwall to the Nord-Calabrese Unit)

128 between Monte Sacro and Monte Centaurino and in the northeastern area, between the 129 villages of Magliano Nuovo and Cicerale. 
135 The Crete Nere $\mathrm{Fm}$ is characterized by the superposition of three fold sets $\left(\mathrm{F}_{1}{ }^{\mathrm{NC}}, \mathrm{F}_{2}{ }^{\mathrm{NC}}\right.$ and

$\left.136 \mathrm{~F}_{3}{ }^{\mathrm{NC}}\right)$ and associated planar and linear structures. The main foliation in pelitic layers is a slaty

137 cleavage $\left(\mathrm{S}_{1}{ }^{\mathrm{NC}}\right)$ sub-parallel to $\mathrm{F}_{1}{ }^{\mathrm{NC}}$ fold axial planes $\left(\mathrm{AP}_{1}{ }^{\mathrm{NC}}\right)$, whereas in the competent

138 arenitic beds a spaced, disjunctive cleavage is present. $\mathrm{F}_{1}{ }^{\mathrm{NC}}$ folds display geometries ranging

139 from tight to isoclinal (Fig. 5a). Fold shape alternates between classes 1c and 3 of Ramsay

140 (1967) in competent and incompetent units, respectively. $F_{2}{ }^{N C}$ folds are characterized by

141 larger interlimb angles with respect to preexisting $\mathrm{F}_{1}{ }^{\mathrm{NC}}$ folds. Fold interference patterns

142 range from perfectly coaxial (type 3; Ramsay, 1967) to moderately non-coaxial (intermediate

143 type 2-3, Fig 5a). A crenulation cleavage $\left(\mathrm{S}_{2}{ }^{\mathrm{NC}}\right)$ and a crenulation lineation $\left(\mathrm{L}_{2}{ }^{\mathrm{NC}}\right)$ occur in the

144 pelitic units. Bedding $\left(\mathrm{S}_{0}{ }^{\mathrm{NC}}\right)$ is marked by the occurrence of arenitic beds or by layers of

145 differing composition and color in the fine-grained layers. A macro-scale fold (here termed

146 Orria Syncline, as it is exposed around the Orria village; Fig. 3a) and related parasitic folds

$147 \mathrm{~F}_{3}{ }^{\mathrm{NC}}$ deform this succession in the NE sector of the study area, whereas rare meso-scale $\mathrm{F}_{3}{ }^{\mathrm{NC}}$ 148 folds occur elsewhere.

149 Orientation data for the main structures exposed between Pisciotta Marina and Pioppi (Fig.

1503 3) are shown in Fig. 6. Bedding and $\left(S_{1}{ }^{N C}\right)$ foliation poles (Figs. 6a, f) form two girdles

151 providing theoretical $\left(\pi_{1}\right.$ and $\pi_{2}$ ) fold axes plunging $055 / 07$ and $065 / 16$, respectively. (The

152 latter value, obtained from folded $S_{1}{ }^{N C}$, is related to second-phase folds). $F_{1}{ }^{N C}$ and $F_{2}{ }^{N C}$ folds

153 are about coaxial: mesoscopic fold hinges $A_{1}{ }^{N C}$ (Fig. 6b) show a mean plunge of 051/19 and

154 mesoscopic fold hinges $\mathrm{A}_{2}{ }^{\mathrm{NC}}$ (Fig. $6 \mathrm{~g}$ ) form a cluster around the mean value of $064 / 12$

155 whereas in the Pioppi area $\mathrm{A}_{1}{ }^{\mathrm{NC}}$ data (Fig. 6c) define a girdle. The crenulation lineation $\left(\mathrm{L}_{2}^{\mathrm{NC}}\right)$

156 is parallel to $\mathrm{A}_{2}{ }^{\mathrm{NC}}$ fold hinges (Fig. 6h), to which is clearly related, and displays a mean plunge

157 of $066 / 12$. The axial planes $A P_{1}{ }^{N C}$ of $F_{1}{ }^{N C}$ folds are dipping mainly to the SE (Fig. $6 \mathrm{~d}$ ) in the

158 Pisciotta Marina area, whereas in the Pioppi area they are scattered (Fig. 6e). The axial 
159 planes $\mathrm{AP}_{2}{ }^{\mathrm{NC}}$ of $\mathrm{F}_{2}{ }^{\mathrm{NC}}$ folds dip both to the NW and SE in the Pisciotta Marina area (Fig. 6i).

160 Poles to the associated crenulation cleavage $\left(\mathrm{S}_{2}{ }^{\mathrm{NC}}\right)$ form two clusters including both

161 moderately SSE dipping and NNW gently dipping sets (Fig. 6j).

162 The third fold set $\left(\mathrm{F}_{3}{ }^{\mathrm{NC}}\right)$ is well-exposed in the Pioppi area. $\mathrm{A}_{3}{ }^{\mathrm{NC}}$ fold hinges (Fig. $6 \mathrm{k}$ ) cluster

163 around a mean value of $301 / 19$, while fold axial planes are dominantly NE to SW dipping 164 (Fig. 6l).

165

166

\subsection{3 .2 Saraceno $\mathrm{Fm}$.}

167

168 Structural analysis on the Saraceno Fm has been carried out separately for the pelitic-

169 calcareous lower part (Punta Telegrafo Member) and for the arenitic-marly middle-upper

170 portion. The analyzed lower part of the formation crops out at Pisciotta Marina, Punta

171 Telegrafo and Torre di Caleo (Fig. 3a). The Punta Telegrafo Member is characterized by the

172 superposition of two meso-scale fold sets $F_{1}{ }^{N C}$ and $F_{2}{ }^{N C}$ (Fig. $5 b$ ). $F_{1}{ }^{N C}$ folds show tight to

173 isoclinal geometries, with shapes ranging from chevron, rounded and box types (Fig. 5b).

174 Generally $\mathrm{F}_{1}{ }^{\mathrm{NC}}$ folds in pelitic rocks are of class 3 of Ramsay (1967), whereas they are of class

$1751 \mathrm{l}$ for calcareous and arenitic layers. Second-phase folds $\left(\mathrm{F}_{2}{ }^{\mathrm{NC}}\right)$ include open to tight folds

176 (Fig. 5b) that are locally intensely developed (Fig. 5d). Variably developed cleavages are

177 associated with the two fold sets. In the pelites, the first foliation $\left(\mathrm{S}_{1}{ }^{\mathrm{NC}}\right)$ is a roughly axial

178 planar slaty cleavage (involving total or partial transposition), whereas the second foliation

$179\left(\mathrm{~S}_{2}{ }^{\mathrm{NC}}\right)$ is a crenulation cleavage (Fig. $\left.5 \mathrm{c}\right)$ to which a crenulation lineation $\left(\mathrm{L}_{2}{ }^{\mathrm{NC}}\right)$ is also

180 associated. Late, open $\mathrm{F}_{3}{ }^{\mathrm{NC}}$ folds refold this part of succession.

181 Complex vein arrays affect the whole calcareous succession, especially at Punta Telegrafo

182 site (Fig. 5f). Most of the veins are orthogonal to $F_{1}{ }^{N C}$ fold hinges or form conjugate sets, 
183 often in the form of en-echelon vein arrays, both indicating extension parallel to the fold axis

$184 \mathrm{~A}_{1}{ }^{\mathrm{NC}}$. Veins parallel to $\mathrm{A}_{1}{ }^{\mathrm{NC}}$ also occur, producing a characteristic chocolate tablet boudinage

185 (Fig. 5f). Locally, especially in the isoclinal fold limbs, intense stretching occurs in the form of 186 conjugate ductile shear zones (Fig. 5e) or as asymmetric boudinage (Fig. 5g). Extension veins

187 orthogonal to $\mathrm{F}_{2}{ }^{\mathrm{NC}}$ fold hinges also occur, although they are less common. For both folding

188 events, fold amplification was preceded by homogeneous shortening (bedding-parallel

189 shortening for the first event), expressed by local thrust faults characterized by minor

190 displacements (pre-buckle thrusts; Price and Cosgrove, 1990). Often the second shortening

191 affects previously boudinaged layers (Fig. 5h). The interference pattern developed by the

192 superposition of $\mathrm{F}_{1}{ }^{\mathrm{NC}}$ and $\mathrm{F}_{2}{ }^{\mathrm{NC}}$ fold sets is of intermediate 2-3 type of Ramsay's (1967)

193 classification (Fig. $5 b$ ), $F_{2}{ }^{N C}$ fold hinges forming a generally low angle with $F_{1}{ }^{N C}$ fold axes.

194 Nearly coaxial refolding is recorded by the distribution of bedding attitudes, the composite

195 structures resulting from fold superposition maintaining an overall sub-cylindrical geometry.

196 Poles to $\mathrm{S}_{0}^{\mathrm{NC}}$ form girdles (Fig. 7a, b) indicating theoretical $\left(\pi_{1}\right)$ fold axes of $064 / 09$ (Punta

197 Telegrafo) and 231/21 (Torre di Caleo). Poles to $\mathrm{S}_{1}{ }^{\mathrm{NC}}$ (Fig. 7g) are also distributed around a

198 great circle whose pole plunges $237 / 06$, this value representing the theoretical $\left(\pi_{2}\right)$ fold axis

199 for the second-phase fold set. First-phase fold hinges $\left(A_{1}{ }^{N C}\right)$ are scattered (Fig. $\left.7 c, e\right)$.

200 However, the related axial planes $\left(\mathrm{AP}_{1}{ }^{\mathrm{NC}}\right)$ dip mainly to the NW and SE (Fig. $7 \mathrm{~d}, \mathrm{f}$ ).

201 Conversely, second-phase fold hinges $\left(\mathrm{A}_{2}^{\mathrm{NC}}\right)$ form a subhorizontal cluster (Fig. $\left.7 \mathrm{~h}, \mathrm{k}, \mathrm{m}\right)$ with

202 mean plunges of 037/06 (Pisciotta Marina), 042/00 (Punta Telegrafo) and 066/12 (Torre di

203 Caleo). The related fold axial planes $\left(\mathrm{AP}_{2}{ }^{\mathrm{NC}}\right.$ ) dip mainly to the NW and SE (Fig. 7j, I, n). A

204 crenulation cleavage $\left(\mathrm{S}_{2}{ }^{\mathrm{NC}}\right)$ and a crenulation lineation $\left(\mathrm{L}_{2}^{\mathrm{NC}}\right)$ are associated with second-

205 phase folds. $\mathrm{S}_{2}^{\mathrm{NC}}$ surfaces tend to dip either moderately to the NW or gently to the SE (Fig.

206 70), whereas lineations $\mathrm{L}_{2}{ }^{\mathrm{NC}}$ form a cluster with a mean plunge of 248/04 (Fig. 7i). 
207 The middle-upper part of the Saraceno Fm is characterized by structures similar to those

208 described for the lower part, although $\mathrm{F}_{3}{ }^{\mathrm{NC}}$ folds become more abundant. As for the Punta

209 Telegrafo Member, this part of the succession is characterized by three fold sets: $\mathrm{F}_{1}{ }^{\mathrm{NC}}, \mathrm{F}_{2}{ }^{\mathrm{NC}}$

210 and $F_{3}{ }^{N C}$. Generally $F_{1}{ }^{N C}$ folds are tight to isoclinal and show variable geometries with

211 chevron to rounded shapes, whereas $\mathrm{F}_{2}{ }^{\mathrm{NC}}$ folds are more open (Fig. 8a, b). Poles to bedding

212 are scattered (Fig. 7p) with dominant NW and SE dip directions. $F_{1}{ }^{N C}$ fold hinges and axial

213 planes are also scattered (Fig. $7 q, r)$. The related cleavage $\left(\mathrm{S}_{1}{ }^{\mathrm{NC}}\right)$ dips mainly to the $\mathrm{NW}$ and

214 SE (Fig. 7s). $F_{2}{ }^{N C}$ fold hinges plunge mainly to the NNE and S/WSW (Fig. 7t). $F_{2}{ }^{N C}$ fold axial

215 planes are mainly gently dipping to sub-horizontal (Fig. 7u), similarly to the related

216 crenulation cleavage $\mathrm{S}_{2}{ }^{\mathrm{NC}}$ (Fig. $7 \mathrm{v}$ ). As for the lower part of the formation, also here

217 interference patterns between $\mathrm{F}_{1}{ }^{\mathrm{NC}}$ and $\mathrm{F}_{2}{ }^{\mathrm{NC}}$ folds are of intermediate type between types 2

218 and 3 of Ramsay's (1967) classification (Fig. 8a, b). $F_{3}{ }^{N C}$ folds generally display open to tight

219 shapes, with dominantly W-E trending hinges (Fig. 7w) and axial planes dipping mainly to the

220 S and secondarily to the N (Fig. 7x). The previously mentioned Orria Syncline, representing a

221 regional $\mathrm{F}_{3}{ }^{\mathrm{NC}}$ structure, involves also the Saraceno $\mathrm{Fm}$ in the NE part of the study area.

222

223

4 4. Structural analysis of the Cilento Group

224

225 In order to unravel possible stratigraphic controls on structural development and to analyze

226 the role of bed-thickness on folding style, (i) the lower part (Cannicchio Sandstones M ember)

227 of the Pollica Fm, (ii) the middle-upper part of the Pollica Fm, and (iii) the San Mauro Fm

228 have been analyzed separately. The analyzed outcrops are localized around the Pollica,

229 Omignano, Orria, Gioi, Salento and Catona villages (Fig. 3a). 


\subsection{1 Lower part of the Pollica Fm: Cannicchio}

234 Several outcrops of the Cannicchio Sandstones Member have been analyzed, particularly in

235 the Cannicchio type-locality (close to the Pollica village; Fig. 3a). In this area the succession is characterized by $\left(\mathrm{F}_{1}{ }^{\mathrm{CG}}\right)$ folds showing kink and chevron shapes (fig $8 \mathrm{c}$ ), and subordinate rounded or box geometries. These folds are often detached along pelitic layers (Fig. 8c)

238 forming SE verging asymmetric fold trains characterized by overturned short limbs. It is common to find stiff beds sandwiched between pelitic layers and shortened by NW or SE

240 dipping pre-buckle thrusts showing minor displacements (Fig. 8d). Minor thrust faults occur also in fold hinge regions to accommodate shortening in thinner layers (Fig. 8c, inset). In the

242 Omignano area (Fig. 3a) the whole succession is deformed by a SE verging, overturned

243 macro-scale $\mathrm{F}_{1}{ }^{\mathrm{CG}}$ fold and associated parasitic structures. In the area between Omignano,

244 Pollica and Ogliastro, $\mathrm{F}_{1}{ }^{\mathrm{CG}}$ fold hinges of both meso- and macro-scale folds show a general

245 NE-SW trend. A spaced, disjunctive cleavage $\left(\mathrm{S}_{1}{ }^{\mathrm{CG}}\right)$ is associated with these folds.

246 Conversely, in the Orria, Gioi and Cardile areas the whole succession of the Cilento Group is

247 deformed by the SW-S verging regional Orria Syncline (Zuppetta and Mazzoli, 1997), which

248 represents a $\mathrm{F}_{1}{ }^{\mathrm{CG}}$ structure in terms of the Cilento Group deformation.

249 Figure 9 (a to h) shows orientation data for the main analyzed structures. Poles of bedding 250 form girdles (Fig. 9a-c) providing theoretical $\left(\pi_{1}\right)$ fold axes plunging 229/06 (Cannicchio),

$251048 / 13$ (Omignano) and 248/01 (Salento-Orria area). $\mathrm{F}_{1}{ }^{\mathrm{CG}}$ fold hinges are clustered (Fig. 9d, f)

252 around two maxima plunging $240 / 31$ and $047 / 02$, whereas fold axial planes $\mathrm{AP}_{1}{ }^{\mathrm{CG}}$ dip mainly 253 to the NW and SE (Fig. 9e, g). Top-to-the-NW and -SE reverse fault kinematics are compatible 254 with NW-SE shortening (Fig. 9h). 


\subsection{2 Middle-upper part of the Pollica Fm}

257

258 Meso-scale $\mathrm{F}_{1}{ }^{\mathrm{CG}}$ folds are generally asymmetric and show geometries ranging from open to

259 tight, with chevron, rounded, box and kink shapes (Fig. 8e, f). Deformation in fold hinge

260 regions is often accommodated by thrust faults or by cataclasis producing intense

261 brecciation (Fig. 8f). Also in this part of the succession, pre-buckle thrusts commonly affect

262 single stiff layers (Fig. 8g, h, i). In the Omignano area (Fig. 3a) minor parasitic folds are

263 related to the previously mentioned overturned, SE verging major $\mathrm{F}_{1}{ }^{\mathrm{CG}}$ fold. The middle-

264 upper part of the Pollica Fm is also deformed by the previously mentioned regional fold and associated S-SW verging parasitic folds in the Orria-Gioi area.

266 Poles to bedding distributions (Fig. 9i-n) provide theoretical $\left(\pi_{1}\right)$ fold axes plunging $068 / 19$

267 (Ogliastro-Agnone), 208/22 (Pollica), 261/16 (Catona), 045/10 (Omignano), 255/02 (Orria-

268 Piano Vetrale), and 322/03 (Gioi-Cardile). $F_{1}{ }^{C G}$ fold hinge lines (Fig. 9o, p) display mean 269 plunges of 069/09 (Ogliastro-Agnone) and 028/10 (Omignano), whereas fold axial planes dip

270 mainly to the SE in the Ogliastro-Agnone area (Fig. 9q) and both to SE and NW in the 271 Omignano area (Fig. 9r).

272

273

\subsection{3 San Mauro Fm}

274

275 The San M auro Fm crops out mainly in the N and NE sectors of the study area. In the former

276 it shows only gentle $F_{1}{ }^{C G}$ folds, whereas in the latter it is deformed by the previously

277 mentioned regional $\mathrm{F}_{1}{ }^{\mathrm{CG}}$ fold and associated open to tight parasitic folds with steep to gently

278 dipping axial planes and fold vergence ranging between SE and SW. In this formation, 
mesoscopic folds develop overturned limbs only locally (Cardile and Gioi villages) and display larger wavelengths with respect to $\mathrm{F}_{1}{ }^{\mathrm{CG}}$ folds in the underlying Pollica Fm.

Poles to bedding (Fig. 9s-u) indicate gentle folding in the Omignano area (Fig. 9s), whereas in

282 the Orria-Piano Vetrale and Gioi-Cardile areas they form girdles (Fig. 9t, u) providing theoretical $\left(\pi_{1}\right)$ fold axes plunging $286 / 01$ and $127 / 04$, respectively (these being related to

284 the regional Orria Syncline). Fold hinges are scattered (Fig. 9v), whereas fold axial planes dip 285 mainly to the NNE and SSW (Fig. 9w).

The Crete Nere and Saraceno fms, forming the Nord-Calabrese Unit, show similar polyphase deformation $\left(D^{N C}{ }_{1}, D^{N C}\right.$ and $\left.D^{N C}\right)$ characterized by three superposed fold sets $\left(F_{1}{ }^{N C}, F_{2}{ }^{N C}\right.$ and

$291 \mathrm{~F}_{3}{ }^{\mathrm{NC}}$ ). The almost coaxial geometry of the first two fold sets and the limited temporal range

292 in which they must have occurred suggests that the two folding events developed as part of a progressive deformation event characterized by roughly NW-SE shortening. Initial layerparallel shortening during the $D^{\mathrm{NC}}{ }_{1}$ deformation stage produced mesoscopic thrust faults showing minor displacements (pre-buckle thrusts). Subsequent fold amplification led to the development of dominantly isoclinal folds $\left(\mathrm{F}_{1}{ }^{\mathrm{NC}}\right)$. This process was accompanied, especially in the calcareous beds (lower part of the Saraceno Fm), by boudinage and formation of enechelon vein arrays. Boudinage is intensely developed at the transition between the Crete Nere and Saraceno Fms, where the strata are often completely disrupted by conjugate extensional shear zones. Widespread veining reveals significant fluid localization at this level of the succession, a process probably controlled by the stratigraphic boundary between the

302 low permeable shales and slates of the Crete Nere Fm and the high permeable limestones 
303 forming the lower part of the Saraceno Fm. Veins, boudins and conjugate shear zones

304 indicate extension along both the maximum $(\mathrm{X})$ and intermediate $(\mathrm{Y})$ axes of the bulk finite

305 strain ellipsoid (i.e. oblate strain). Furthermore the occurrence of stretched isoclinal folds

306 (intrafolial folds) and shortened boudins strengthens the hypothesis of progressive

307 deformation. The layers were first shortened (by buckling) and then, as fold limbs came to lie

308 roughly parallel to the maximum extension direction as a result of isoclinal folding, they

309 were stretched, leading to the development of intrafolial folds. Such previously lengthened

310 fold limbs, characterized by boudinage of the stiff layers, were subsequently shortened

311 (locally developing 'folded boudins'; Ramsay and Huber, 1983) during the second

312 deformation stage. This $\left(\mathrm{D}^{\mathrm{NC}}\right)$ is characterized by tight to open $\left(\mathrm{F}_{2}{ }^{\mathrm{NC}}\right)$ folds, verging mainly to

313 the SE and subordinately to the NW. The almost coaxial geometry of $\mathrm{F}_{1}{ }^{\mathrm{NC}}$ and $\mathrm{F}_{2}{ }^{\mathrm{NC}}$ fold sets,

314 evident for the Crete Nere Fm and the lower part of the Saraceno Fm, is less consistent for

315 the middle-upper part of the Saraceno $\mathrm{Fm}$, resulting in interference patterns ranging

316 between types 2 and 3 of Ramsay (1967). The third deformation stage $\left(\mathrm{D}_{3}{ }_{3}\right)$ is characterized

317 by the local development of meso- and macro-scale $\mathrm{F}_{3}{ }^{\mathrm{NC}}$ folds (such as in the Pisciotta-Ascea

318 and Orria areas, Fig. 3a) displaying open to tight geometries.

319 The structural evolution unraveled for the Crete Nere and Saraceno fms is comparable with

320 that of the Parasicilide Unit cropping out in Cilento and forming, together with the Nord-

321 Calabrese Unit, the Liguride Units in this area. The Parasicilide Unit, located in the footwall to

322 the Nord-Calabrese Unit, is also characterized by superposed deformations (Vitale et al.,

323 2010): $F_{1}{ }^{P S}$ isoclinal folds, related to a first deformation stage $\left(D^{P S}{ }_{1}\right)$, are refolded by close $F_{2}{ }^{P S}$

324 folds developed in the form of a regional recumbent fold verging to the SE and associated

325 parasitic folds $\left(D^{P S}\right)$. A third deformation event $\left(D^{P S}\right)$ produced open $F_{3}{ }^{P S}$ folds displaying

326 horizontal axial planes, developed only in the steep to vertical $\mathrm{F}_{2}{ }^{\mathrm{PS}}$ limbs. The first two 
327 deformation stages are related to the accretion of this succession into the tectonic wedge in

328 Burdigalian time and subsequent deformation within the wedge (Vitale et al., 2010). Like the

329 Nord-Calabrese Unit, the Parasicilide succession is also deformed, in the NE part of the study

330 area, by the regional $\left(\mathrm{F}_{3}{ }^{\mathrm{PS}}\right)$ Orria Syncline.

331 A late, extensional origin of the contacts between the Nord-Calabrese and Parasicilide Units

332 is suggested by the geometry of the tectonic contact in the Castelnuovo Cilento tectonic

333 window (Fig. 3a, cross sections of Fig. 3b), which dramatically cuts all folds in both footwall

334 and hanging-wall units (Vitale et al., 2010), as well as in the Sapri area, where the Nord-

335 Calabrese Unit directly overlies the Apennine Platform succession with the tectonic omission

336 of the Parasicilide Unit and part of the Crete Nere Fm. The simple restoration provided in Fig.

33710 shows the proposed interpretation for the development of the present structural

338 geometry as well as of wedge-top basin depocentres filled by the Cilento Group deposits.

339 The horizontal extension producing the two major low-angle normal faults shown in Fig. 10

340 is probably associated with previous wedge overthickening, as a result of thrusting of the

341 Nord-Calabrese Unit onto the Parasicilide Unit, as well as with large-scale warping and uplift

342 of the wedge related to footwall imbrication within the underlying Apennine Platform

343 shallow-water to slope carbonates (Vitale et al., 2010). Probably the accretionary wedge

344 collapsed as it exceeded the critical taper, leading to the development of extensional

345 detachments dipping toward the foreland. This processes, together with accretion of new

346 material at the wedge toe, allowed the slope surface angle to decrease.

347 The tectonic contact between the Nord-Calabrese Unit and the Parasicilide Unit is gently

348 folded by broad NE-SW trending antiforms, probably related to footwall imbrication as

349 shown in the geological section $X-X^{\prime}$ in Fig. $3(b)$. This suggests that thrusting involving the

350 Apennine Platform succession and wedge collapse were roughly coeval. Probably part of the 
351 Apennine Platform succession (Monte Bulgheria; Fig. 3a) was exposed already in Middle

352 Miocene time, feeding the Cilento Group with calcareous fine-grained sediments (San M auro

353 Fm). In this case, the tectonic window of Castelnuovo Cilento (Alento Valley; Fig. 3a) may be

354 interpreted as a breached anticline related to thrusting in the underlying Apennine Platform 355 succession.

356 The deformation of the Cilento Group succession, unconformably overlying the previous

357 units, is characterized by a roughly NW-SE oriented shortening ( $\left.D^{C G}{ }_{1}\right)$ expressed by pre-

358 buckle thrusts, reverse faults and asymmetric folds characterized by a main vergence toward

359 the SE and secondarily toward the NW, S and SW. These $\mathrm{F}_{1}{ }^{\mathrm{CG}}$ folds generally range from tight

360 to open and show kink geometries. Folding occurred at very low-T conditions, as evidenced

361 by brittle deformation associated with tight folds. In the NE sector of the study area, the

362 successions belonging to the Cilento Group and the underlying Nord-Calabrese and

363 Parasicilide units are all deformed by the regional Orria Syncline (Fig. 3a). This major fold is

364 accompanied by a system of S-SW overturned parasitic folds (cross section $Y-Y^{\prime}$ in Fig. 3b).

365 The $\pi_{1}$-axes obtained from the poles to bedding measured in the Pollica and San Mauro Fms

366 from different areas (Fig. 9c, m, n, t, u) point out an overall curved fold hinge for the regional

367 fold. Statistical $\left(\pi_{1}\right)$ fold axes plunge from 248/01 (Cannicchio M ember), to 255/02 (M iddle-

368 upper part of Pollica Fm), to 286/01 (San Mauro Fm) in the Orria area, to 322/05 (M iddle-

369 upper part of Pollica Fm) and 127/04 (San Mauro Fm) in the Gioi area. According to Zuppetta

370 and Mazzoli (1997), the general lack of cleavage development and of grain-scale

371 deformation associated with the Orria Syncline is indicative of large-scale folding occurring in

372 not completely lithified sediments. Based on this evidence, the authors suggested an early

373 (syndiagenetic) origin for this fold, involving the Cilento Group sediments immediately

374 following their deposition. Deformation involving non-completely lithified sediments within 
375 the general framework of thrusting and associated non-coaxial strain may have enhanced

376 non-cylindrical folding.

377 In order to obtain a synoptic view of the fold trends in the whole study area, mesoscopic fold

378 axis trends (both for the Liguride Units and the Cilento Group) are plotted in the geological

379 map of Fig. 3a. It is worth noting that a broad homogeneity in fold axis trends exists for the

380 Liguride Units $\left(\mathrm{F}_{1-2-3}^{\mathrm{NC}}, \mathrm{F}_{1-2-3}^{\mathrm{PS}}\right)$ and for the Cilento Group $\left(\mathrm{F}_{1}^{\mathrm{CG}}\right)$. The rough coaxiality between

381 the first fold set $\left(\mathrm{F}_{1}^{\mathrm{CG}}\right)$ in the Cilento Group and $\mathrm{F}_{1-2-3}^{\mathrm{NC}}$ and $\mathrm{F}_{1-2-3}^{\mathrm{PS}}$ fold sets in the Nord-

382 Calabrese and Parasicilide Units suggests a more or less constant orientation of regional

383 shortening for these deformation stages.

384 Although asymmetric folds and kinematic features associated with thrust faults indicate both

385 NW and SE vergences, it is reasonable to suppose a main SE/E tectonic transport for these

386 units according to Miocene kinematic reconstructions proposed by several authors (e.g.

387 Vignaroli et al., 2009 and references therein). This is consistent with the SE vergence of first-

388 phase isoclinal folds in the Parasicilide Unit exposed in the tectonic window of Castelnuovo

389 Cilento (Fig. 3a; Vitale et al., 2010), as well as with top-to-the-ESE kinematics unraveled by

390 Vitale and M azzoli (2009) for carbonate thrust sheets originally forming part of the Apennine

391 Platform in the Calabria-Lucania border area (lannace et al., 2007). Major differences in

392 deformation styles occur between the Liguride Units and the Cilento Group. The Liguride

393 Units show pervasive deformation, whereas the Cilento Group is characterized by locally

394 disharmonic folding and variable fold geometries. Increasing fold wavelength from the

395 bottom to the top of the Cilento succession is probably related to general coarsening and

396 thickening upward (from the thin strata of the Cannicchio Sandstones M ember to the meter-

397 scale strata of the San Mauro Fm). 
398 The Cilento Group was deposited on an already deformed substratum consisting of the

399 Nord-Calabrese and Parasicilide units. Therefore, the first two deformation events involving

400 the latter two units occurred during the Burdigalian, being bracketed by the age of the

401 Cannicchio Member (Burdigalian-Langhian boundary) and the age of the youngest deposits

402 (Arenarie di Albanella Fm, Burdigalian) of the Parasicilide Unit. On the other hand, as

403 suggested by Zuppetta and Mazzoli (1997), based on the analysis of the Orria Syncline and

404 related parasitic structures, deformation of the Cilento Group immediately postdated the

405 deposition of the youngest strata of San M auro Fm (lower Tortonian according to Russo et

406 al., 1995). Deformation stages for the various analyzed successions, their interpreted

407 correlation and chronology are summarized in Table 1.

408 In order to summarize the present results, a geodynamic evolutionary sketch for the 409 southern Apennine accretionary wedge between the Aquitanian-Burdigalian boundary and

410 the post-lower Tortonian is provided in Fig. 11. In the first stage (Fig. 11a) the Nord-

411 Calabrese succession is covered by the foredeep deposits of the Saraceno Fm (sandstones).

412 Subsequently, this unit is incorporated into the accretionary wedge and deformed by overall

413 NW-SE shortening $\left(\mathrm{D}^{\mathrm{NC}}{ }_{1}\right)$ developing isoclinal $\mathrm{F}^{\mathrm{NC}}$ folds (Fig. 11b). During this stage foredeep

414 sedimentation occurs on top of the Parasicilide domain with the deposition of the

415 sandstones of the Arenarie di Albanella Fm. In Burdigalian time (Fig. 11c, d), the Nord-

416 Calabrese Unit experiences continued NW-SE shortening $\left(\mathrm{D}_{2}{ }_{2}\right)$ and the Parasicilide Unit is

417 accreted into the wedge with the development of $\mathrm{F}^{\mathrm{PS}}{ }_{1}$ and $\mathrm{F}^{\mathrm{PS}}$ folds (stages $\mathrm{D}^{\mathrm{PS}}$ and $\mathrm{D}^{\mathrm{PS}}$ ).

418 During the Burdigalian (Fig. 11d), the inner sector of the Apennine Platform carbonate

419 domain is overlain by the accretionary wedge, while sedimentation of the Bifurto Fm occurs

420 in the newly developed foredeep. Later (Fig. 11e, f), the accretionary wedge undergoes

421 horizontal stretching and vertical shortening, probably due to previous overthickening and to 
422 footwall imbrication in the underlying Apennine Platform carbonate succession, producing

423 bending and uplift of the Liguride Units. Low-angle extensional detachments associated with

424 synorogenic extension favor the development of accommodation space in wedge-top basin

425 depocentres (Fig. 11f) that are filled by the Cilento Group deposits (Fig. 11g). Subsequent to

426 the final (early Tortonian) deposition of San Mauro Fm, the whole tectonic pile - including

427 the Nord-Calabrese and Parasicilide Units, as well as the Cilento Group - experiences

428 renewed, though moderate, roughly NW-SE oriented shortening $\left(D^{N C}{ }_{3}, D^{P S}{ }_{1}\right.$ and $\left.D^{C G}{ }_{1}\right)$ leading

429 to the development of scattered folds (Fig. 11h).

\section{6. Conclusions}

433 The integration of available stratigraphic information with new structural data from the

434 various tectonic units exposed in the Cilento area of the southern Apennines has allowed a

435 comprehensive picture of the tectonic evolution of the Liguride accretionary wedge in this

436 area to be obtained. The documented structural data point out that final oceanic subduction

437 stages and early involvement in the deformation of the distal part of the Apulian continental

438 margin were characterized by a broad NW-SE shortening. This, being consistent with recent

439 plate kinematic reconstructions for the Western Mediterranean in Early Miocene times

440 (Schettino and Turco, 2006), is completely unrelated with NE-directed thrusting

441 characterizing the Apennine fold and thrust belt during later (late Tortonian to Quaternary)

442 development of the Apennine-Calabrian-Sicilian arcuate orogen and associated opening of

443 the Tyrrhenian Sea back-arc basin (e.g. Johnston and M azzoli, 2009, and references therein).

444 The progressive development of the accretionary wedge in Miocene times is marked by

445 synorogenic sedimentation both in the trench and in wedge-top basins. Major overthrusting 
446 of Liguride Units, wedge overthickening and subsequent emplacement ('obduction') on top

447 of the Apulian continental palaeomargin were followed by wedge collapse. This was 448 probably coeval with - and partly related to - incipient footwall imbrication within

449 underlying Apennine Platform carbonates. Late deformation of the accretionary wedge, 450 post-dating deposition of the Cilento Group wedge-top basin sediments (ending in the 451 earliest Tortonian), was controlled by renewed more or less NW-SE oriented shortening, 452 thus confirming that the previous wedge thinning episode took place within the general 453 framework of plate convergence.

454 The results, shedding new light into the Miocene tectonic evolution of the southern 455 Apennine accretionary wedge, provide new insights into the early stages of southern 456 Apennines development. This will hopefully contribute to a better understanding of a critical 457 stage of Apennine geodynamics, involving the transition from the subduction of oceanic 458 lithosphere to that of continental lithosphere, prior to the development of the intensely 459 studied NE-directed Apennine foreland fold and thrust belt.

\section{Acknowledgements}

462 Thorough review by Agustin Martin-Algarra and useful comments by JG Editor Randell 463 Stephenson allowed us to substantially improve the paper. We are grateful to Glauco 464 Bonardi for the innumerable and invaluable discussions.

\subsection{References}

467

468 Amore, O., Bonardi, G., Ciampo, G., De Capoa, P., Perrone, V., Sgrosso, I., 1988. Relazioni 469 tra "flysch interni" e domini appenninici: reinterpretazione delle formazioni di Pollica, San 
Mauro e Albidona e il problema dell'evoluzione inframiocenica delle zone esterne

471 appenniniche. Mem. Soc. Geol. It., 41, 285-299.

472 Bonardi, G., Amore, F.O., Ciampo, G., de Capoa, P., Miconnet, P., Perrone, V., 1988. Il

473 Complesso Liguride Auct.: stato delle conoscenze e problemi aperti sulla sua evoluzione pre-

474 appenninca ed i suoi rapporti con l'arco calabro. Mem. Soc. Geol. It., 41, 17-35.

475 Bonardi, G., Cavazza, W., Perrone, V., Rossi, S., 2001. Calabria-Peloritani terrane and 476 northern Ionian Sea. In: G.B. Vai \& I.P. Martini (eds.), Anatomy of an Orogen: the Apennines 477 and Adjacent Mediterranean Basins. Kluwer Academic Publishers, 287-306.

478 Bonardi, G., Caggianelli, A, Critelli, S., Messina, A., Perrone, V., Acquafredda, P., Carbone, 479 G., Careri, G., Cirrincione, R., D’errico, M., Dominici, R., Festa, V., Iannace, A., Macaione, 480 E., Mazzoli, S., Notaro, P., Parente, M., Perri, E., Piluso, E., Somma, R., Sonnino, M., Vitale, 481 S., 2004. Geotraverse across the Calabria-Peloritani Terrane (southern Italy). Field Trip Guide 482 Books vol. VI. Memorie Descrittive della Carta Geologica D’Italia, 63, 1-60.

483 Bonardi, G., Ciarcia, S., Di Nocera, S., Matano, F., Sgrosso, I., Torre, M., 2009. Carta delle 484 principali Unità Cinematiche dell'Appennino meridionale. Boll. Soc. Geol. It., 128, Tav. f. t. 485 Cammarosano, A., Danna, M., De Rienzo, F., Martelli, L., Miele, F. , Nardi, G., 2000. Il 486 substrato del Gruppo del Cilento tra il M. Vesalo e il M. Sacro (Cilento, Appennino 487 Meridionale). Boll. Soc. Geol. It., 119, 395-405.

488 Cammarosano, A., Cavuoto, G., Danna, M., de Capoa, P., de Rienzo, F., Di Staso, A., 489 Giardino, S., Martelli, L., Nardi, G., Sgrosso, A., Toccaceli, R.M., Valente, A., 2004. Nuovi 490 dati sui flysch del Cilento (Appennino meridionale, Italia). Boll. Soc. Geol. It., 123, 253-273.

491 Ciarcia, S., Vitale, S., Di Staso, A., Iannace, A., Mazzoli, S., Torre, M., 2009. Stratigraphy 492 and tectonics of an Internal Unit of the southern Apennines: implications for the geodynamic 493 evolution of the peri-Tyrrhenian mountain belt. Terra Nova, 21, 88-96.

494 Donzelli, G., Crescenti, U., 1962. Lembi di Flysch oligocenico affiorante a SE della Piana del 495 Sele. Mem. Soc. Geol. It., 3, 569-592. 
496 Ghezzi, G., Bayliss, D.D., 1964. Uno studio del flysch nella regione calabro-lucana.

497 Stratigrafia, tettonica e nuove idee sul Miocene dell'Appennino meridionale. Boll. Serv. Geol.

498 d'It., 84, 3-64

499 Guerrera, F., Martín-Martín, M., Perrone, V., Tramontana, M., 2005. Tectono-sedimentary

500 evolution of the southern branch of the Western Tethys (Maghrebian Flysch Basin and

501 Lucanian Ocean): consequences for Western Mediterranean geodynamics. Terra Nova, 17, $502358-367$.

503 Iannace, A., Vitale, S., D’errico, M., Mazzoli, S., Di Staso, A., Macaione, E., Messina, A., 504 Reddy, S.M., Somma, R., Zamparelli, V., Zattin, M., Bonardi, G. 2007. The carbonate 505 tectonic units of northern Calabria (Italy): A record of Apulian paleomargin evolution and 506 Miocene convergence, continental crust subduction, and exhumation of HP-LT rocks. Journal 507 of Geological Society, 164, 1165-1186.

508 Ietto, A., Pescatore, T., Cocco, E., 1965. Il flysch mesozoico-terziario del Cilento occidentale. 509 Boll. Soc. Natur. Napoli, 74, 396-402.

510 Johnston, S.T., Mazzoli, S., 2009. The Calabrian Orocline: buckling of a previously more

511 linear orogen. In: Murphy, J.B., Keppie, J.D., Hynes, A.J., (Eds.). Ancient Orogens and 512 Modern Analogues. Geological Society, London, Special Publications, 327, 113-125, doi: 513 10.1144/SP327.7 0305-8719/09/\$15.00.

514 Mazzoli, S., Helman, M., 1994. Neogene patterns of relative plate motion for Africa-Europe:

515 some implications for recent central Mediterranean tectonics. Geologische Rundschau, 83, $516 \quad 464-468$.

517 Mazzoli, S., D’Errico, M., Aldega, L., Corrado, S., Invernizzi ,C., Shiner, P., Zattin, M. 2008.

518 Tectonic burial and 'young' (<10 Ma) exhumation in the southern Apennines fold and thrust 519 belt (Italy). Geology, 36, 243-246, doi: 10.1130/G24344A.

520 Mostardini, F., Merlini, S., 1986. Appennino centro meridionale. Sezioni geologiche e 521 proposta di modello strutturale. Mem. Soc. Geol. It., 35, 177-202. 
522 Pescatore, T., Sgrosso, I., Torre, M., 1970. Lineamenti di tettonica e sedimentazione nel

523 Miocene dell'Appennino campano-lucano. Mem. Soc. Nat. in Napoli, 78, 337-408.

524 Price, N.J., Cosgrove, J.W., 1990. Analysis of geological structures. Cambridge University 525 Press, Cambridge.

526 Ramsay, J.G., 1967. Folding and fracturing of rocks. McGraw Hill: Book Company, New 527 York.

528 Ramsay, J.G., Huber, M., 1983. The Techniques of Modern Structural Geology. Volume I:

529 Strain Analysis. Academic Press, London.

530 Ranalli, G., Pellegrini, R., D’Offizi, S., 2000. Time dependence of negative buoyancy and the

531 subduction of continental lithosphere, J. Geodyn., 30, 539-555.

532 Russo, M., Zuppetta, A., Guida, A., 1995. Alcune precisazioni stratigrafiche sul Flysch del

533 Cilento (Appennino meridionale). Boll. Soc. Geol. It., 114, 353-359.

534 Selli, R., 1962. Il Paleogene nel quadro della geologia dell'Italia meridionale. Mem. Soc.

535 Geol. It., 3, 737-790.

536 Schettino, A., Turco, E., 2006. Plate kinematics of the Western Mediterranean region during

537 the Oligocene and Early Miocene. Geophys. J. Int., 166, 1398-1423.

538 Vignaroli, G., Faccenna, C., Rossetti, F., Jolivet, L., 2009. Insights from the Apennines

539 metamorphic complexes and their bearing on the kinematics evolution of the orogen. In:, Van

540 Hinsbergen, D.J.J., Edwards, M.A., Govers, R. (Eds.), Collision and Collapse at the Africa-

541 Arabia-Eurasia Subduction Zone. The Geological Society, London, Special Publications, 311,

$542 \quad 235-256$.

543 Vitale, S. Mazzoli S., 2009. Finite strain analysis of a natural ductile shear zone in limestones:

544 insights into 3-D coaxial vs. non-coaxial deformation partitioning. Journal of Structural

545 Geology, 31, 104-113, doi: 10.1016/j.jsg.2008.10.011.

546 Vitale, S., Ciarcia, S., Mazzoli, S., Iannace, A., Torre, M., 2010. Structural analysis of an

547 Internal Unit of the southern Apennines (Cilento area, Italy): new constraints on the 
548 geodynamic evolution of the Miocene Apennine accretionary wedge. Comptes Rendus

549 Geosciences, doi: 10.1016/j.crte.2010.03.005.

550 Zuppetta, A., Mazzoli, S., 1997. Deformation history of a synorogenic sedimentary wedge,

551 northern Cilento area southern Apennines thrust and fold belt, Italy. Geological Society of 552 America Bulletin, 109, 698-708.

553

554 Figure captions

555

556 Fig. 1. Tectonic sketch map of the southern Apennines (after Bonardi et al., 2009, modified).

557 Inset shows thrust front of the peri-Tyrrhenian mountain belt.

558

559

560

Fig. 2. Sketch showing tectonic and stratigraphic relationships between Liguride Units and Miocene wedge-top basin deposits.

561

562

563

Fig. 3. (a) Geological sketch map of the Cilento area, showing all analyzed outcrop locations;
(b) Geological cross-sections (located in a).

564

565 Fig. 4. Sketch showing stratigraphic relationships for the Nord-Calabrese and Parasicilide

566 Units, the Cilento Group and the Monte Sacro Fm.

567

568 Fig. 5. Examples of outcrop features in the Crete Nere Fm (a) and in the lower part of the

569 Saraceno Fm (b) to (h). (a) Interference pattern between isoclinal $F_{1}{ }^{N C}$ and close $F_{2}{ }^{N C}$ folds

570 (Torre di Caleo-Pioppi). (b) Interference pattern between isoclinal $\mathrm{F}_{1}{ }^{\mathrm{NC}}$ and open $\mathrm{F}_{2}{ }^{\mathrm{NC}}$ folds

571 (Punta Telegrafo). (c) Crenulation cleavage $\left(\mathrm{S}_{2}{ }^{\mathrm{NC}}\right)$ deforming preexisting pervasive foliation 
$572\left(\mathrm{~S}_{1}{ }^{\mathrm{NC}}\right)$ (Punta Telegrafo). (d) $\mathrm{F}_{2}{ }^{\mathrm{NC}}$ folds (Punta Telegrafo). (e) Bedding-parallel shear zone 573 consisting of rotated calcareous clasts embedded in foliated pelite (formed by disruption of

574 pre-existing limestone-shale alternations; Pioppi). (f) Chocolate tablet boudinage in

575 calcareous bed (Punta Telegrafo). (g) Rotated boudin (detail of en echelon boudin structure)

576 in calcareous layer embedded in pelite (Torre di Caleo). (h) Shortened boudinage (Torre di

577 Caleo).

578

579 Fig. 6. Lower hemisphere, equal-area projections showing orientation data for measured 580 structures in the Crete Nere Fm.

581

582 Fig. 7. Lower hemisphere, equal-area projections showing orientation data for measured 583 structures in the Saraceno Fm.

584

585 Fig. 8. Examples of outcrop features in the Saraceno and Pollica Fms. Interference between

586 isoclinal $F_{1}{ }^{N C}$ folds and close $F_{2}{ }^{N C}$ folds, middle part of the Saraceno Fm: (a) Torre di Caleo; (b)

587 Ascea-Pisciotta. (c) $\mathrm{F}_{1}{ }^{\mathrm{CG}}$ detachment fold in the Cannicchio Sandstones Member, showing 588 (boxed) accommodation thrusts in thin arenite layer located in the fold hinge region

589 (Cannicchio). (d) Pre-buckle thrust in the Cannicchio Sandstones Member (Cannicchio). (e) 590 Kink fold in the middle part of the Pollica Fm (Agnone). (f) Brecciated sandstone in the hinge

591 region of $\mathrm{F}_{1}{ }^{\mathrm{CG}}$ fold, middle part of the Pollica Fm (Ogliastro Marina). (g)-(h)-(i) Pre-buckle

592 thrusts in competent beds of the middle part of the Pollica Fm (Ogliastro).

593

594 Fig. 9. Lower hemisphere, equal-area projections showing orientation data for measured 595 structures in the Pollica and San Mauro Fms. 
597 Fig. 10. Tectonic model showing present-day geometric relationships among the studied 598 units.

599

600 Fig. 11. Sketch showing the reconstructed geodynamic evolution of the Cilento accretionary 601 wedge between the Aquitanian and the early Tortonian.

602

603 Table caption

604

605 Table 1. Correlation among deformation stages for the studied successions and related 606 chronology.

607 


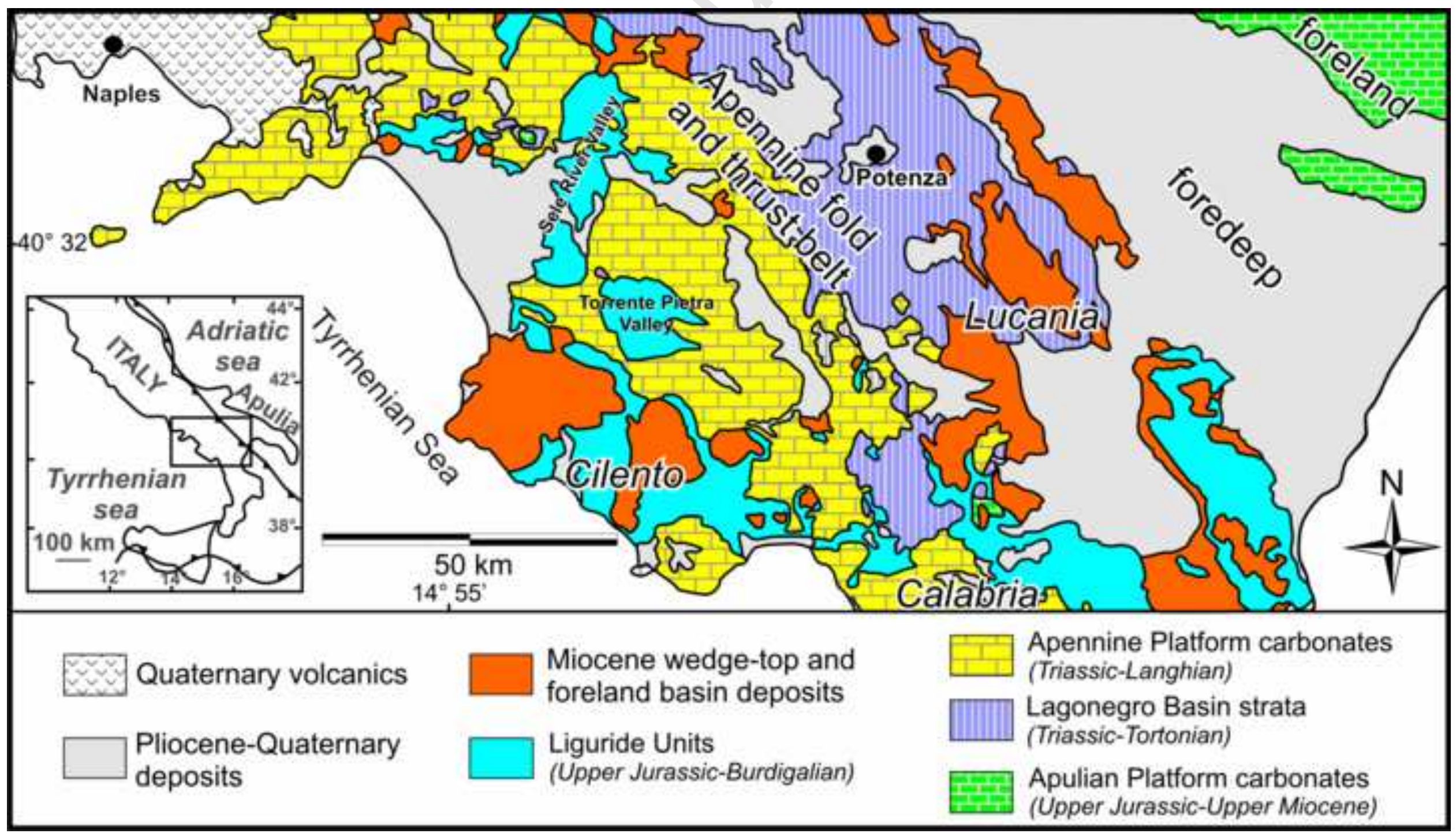




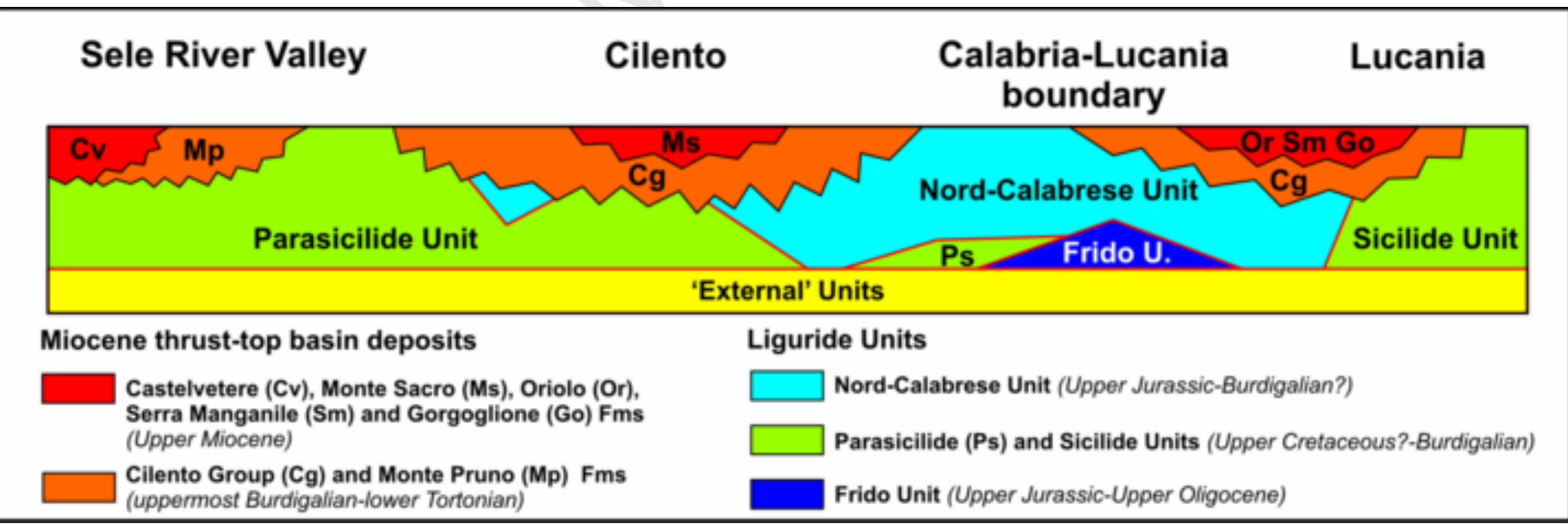




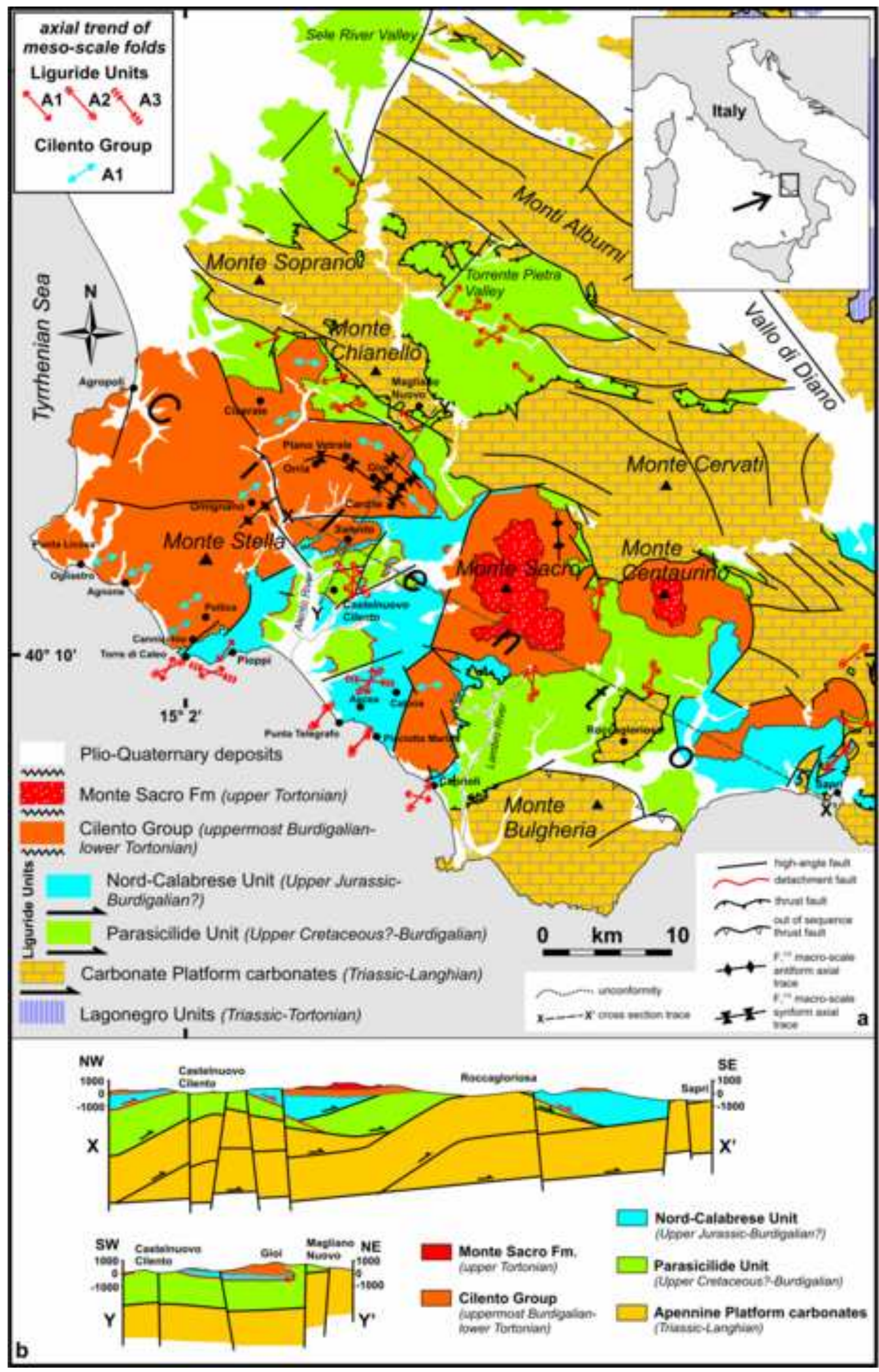




\section{Cilento Accretionary Wedge}

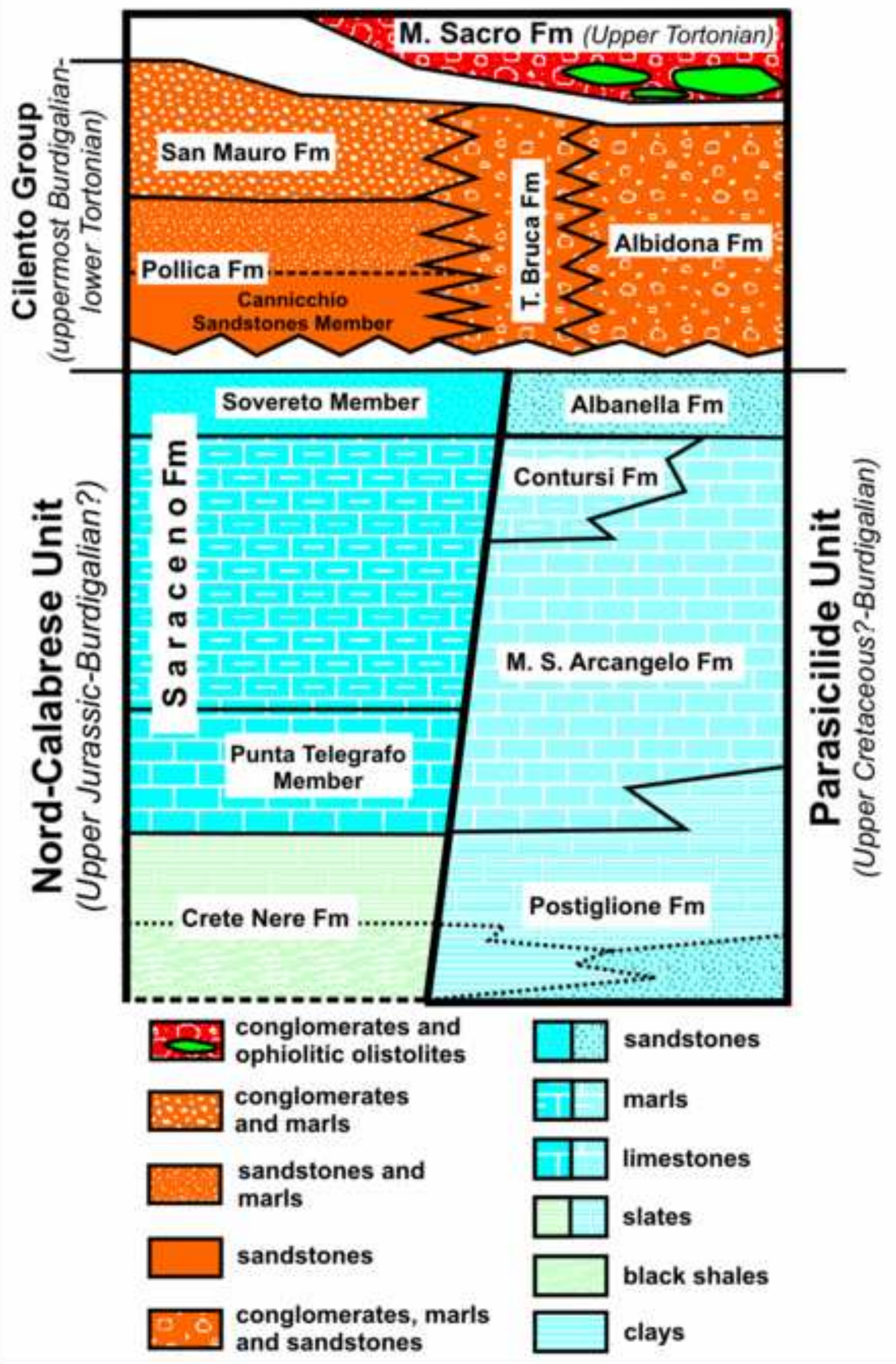



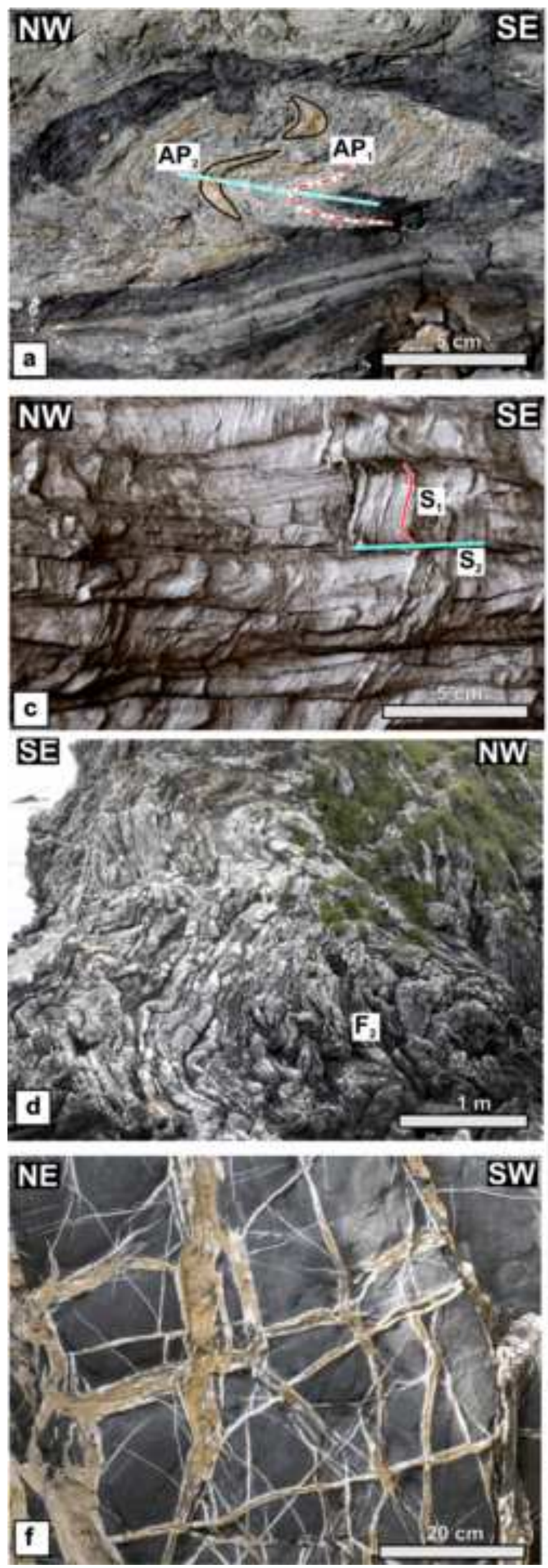
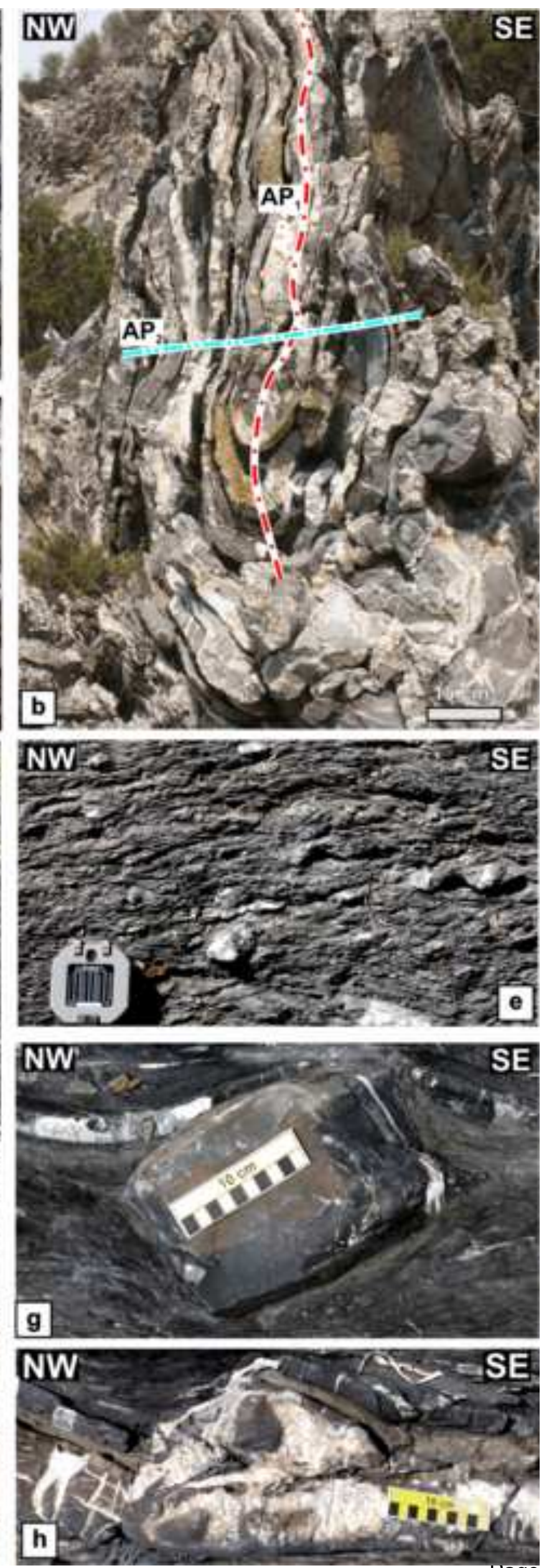


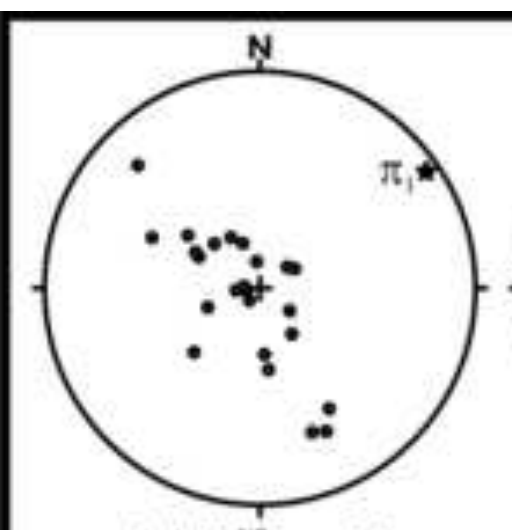

(a) $\mathrm{S}_{0}{ }^{N C}, n=24$

Pisciotta Marina

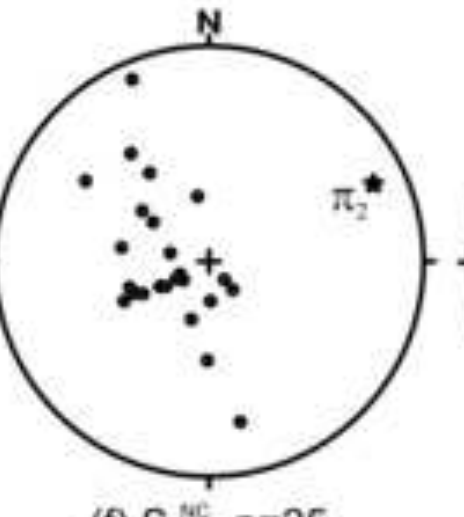

(f) $S_{1}{ }^{\mathrm{NC}}, \mathrm{n}=25$

Pisciotta Marina

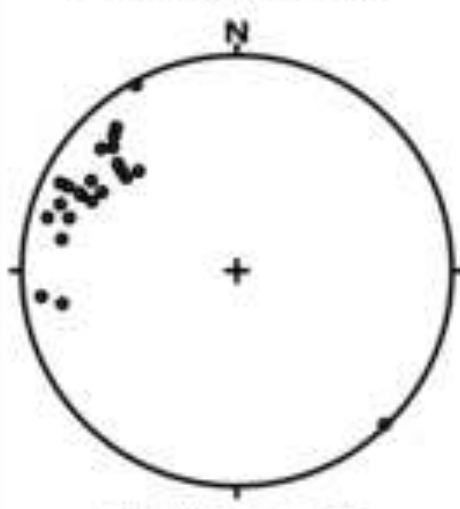

(k) $A_{3}{ }^{N C}, n=23$ Pioppi

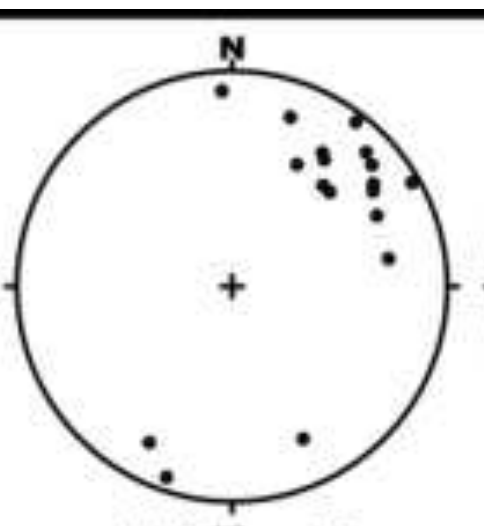

(b) $A_{1}, n=18$

Pisciotta Marina

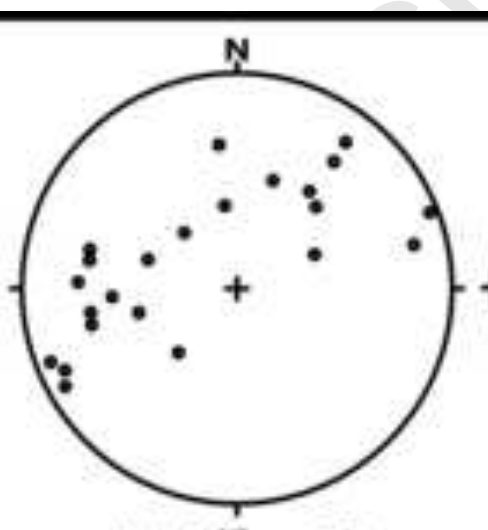

(c) $A_{1}, n=24$ Pioppi

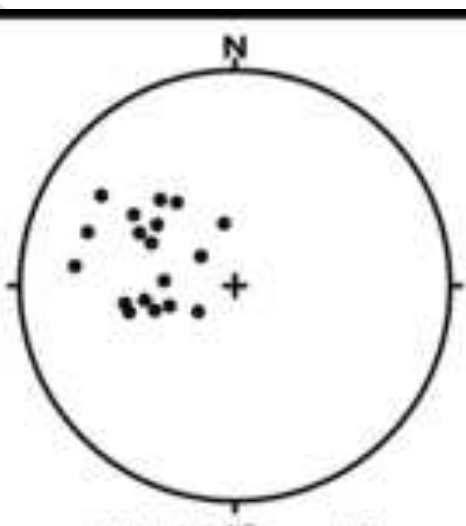

(d) $\mathrm{AP}^{\mathrm{NC}}, \mathrm{n}=18$

Pisciotta Marina

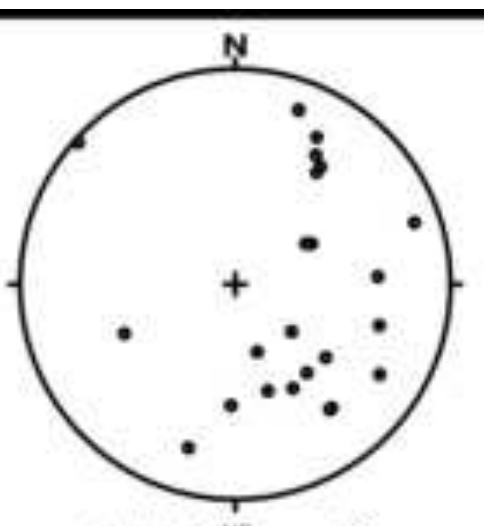

(e) $\mathrm{AP}^{\mathrm{NC}}, \mathrm{n}=18$ Pioppi

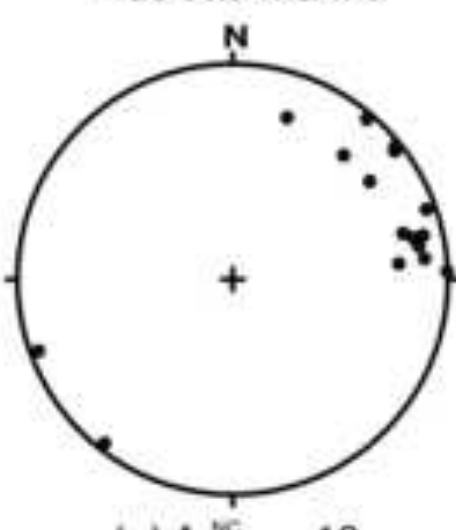

(g) $\mathrm{A}_{2}{ }^{\mathrm{NC}}, \mathrm{n}=16$

Pisciotta Marina

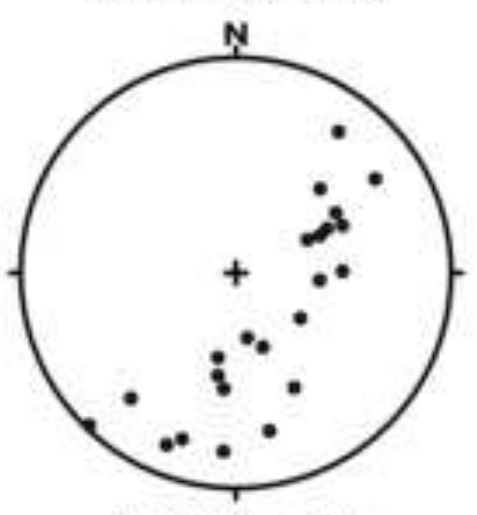

(I) $\mathrm{AP}_{3}{ }^{\mathrm{NC}}, \mathrm{n}=23$ Pioppi

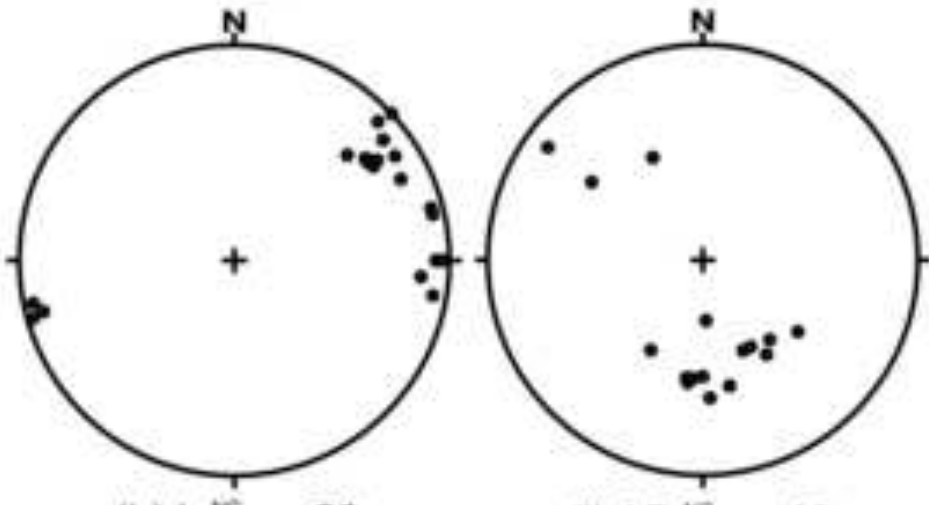

(h) $\mathrm{L}_{2}^{\mathrm{NC}}, \mathrm{n}=20$

Pisciotta Marina (i) $\mathrm{AP}_{2}, \mathrm{n}=16$

Pisciotta Marina

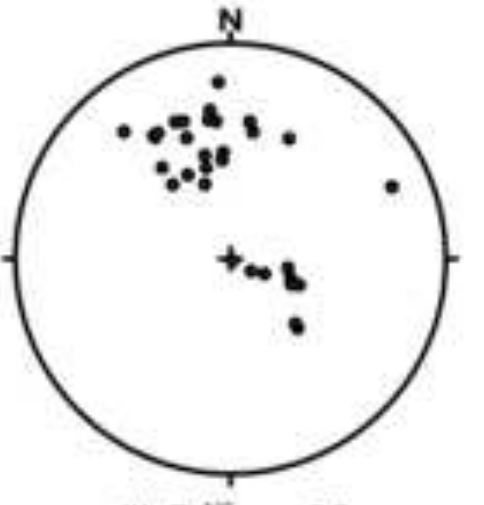

(j) $\mathrm{S}_{2}{ }^{\mathrm{NC}}, \mathrm{n}=32$

Pisciotta Marina 


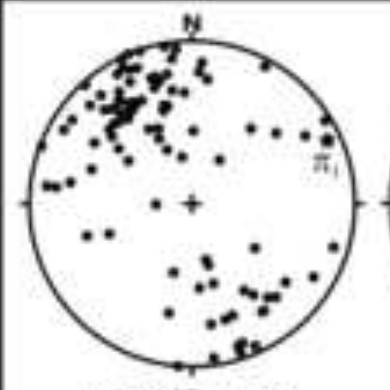

(a) $S_{1}, n=n=96$

Puntatelegrafo

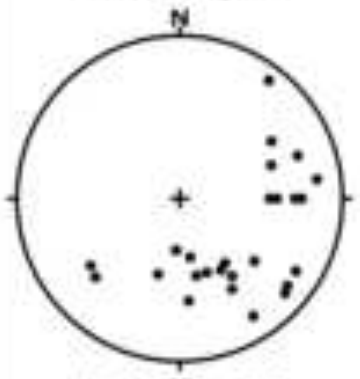

(f) $\mathrm{AP}_{\mathrm{t}}{ }^{*}, n=26$

Torre di Caleo

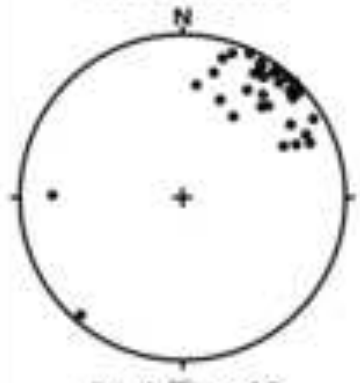

(k) $A^{2}, n=37$

Punta Telegrafo

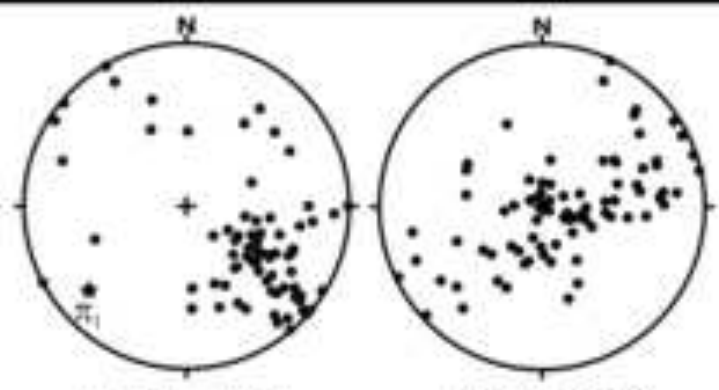

(b) $5, *, n=77$

Torre di Caleo (c) $A_{4}{ }^{11 C}, n=83$

Punta Telegrafo

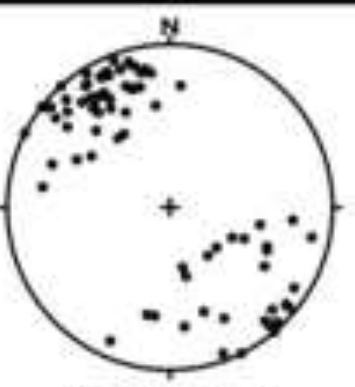

(d) $A P_{1}=1, n=79$

Punta Telegrafo

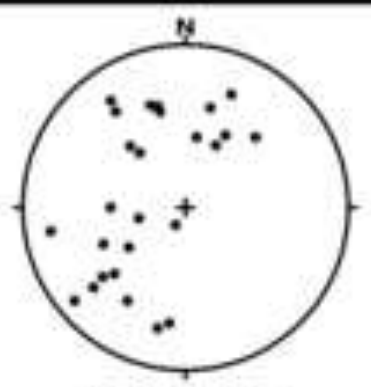

(e) $A_{4}{ }^{16}, \pi=26$

Torre di Caleo

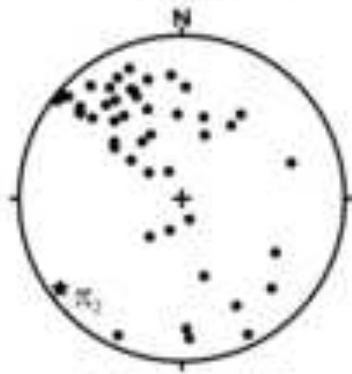

(g) $S, n, n=47$

Punta Telegrafo

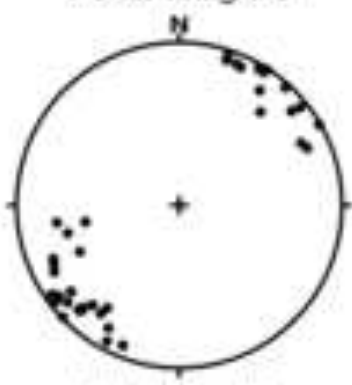

(h) $A_{i}, n=33$

Pisciotta Marina

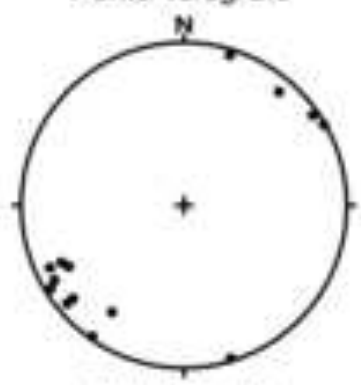

(i) $\mathrm{L}_{t}, \mathrm{~N}=14$

Punta Telegrafo

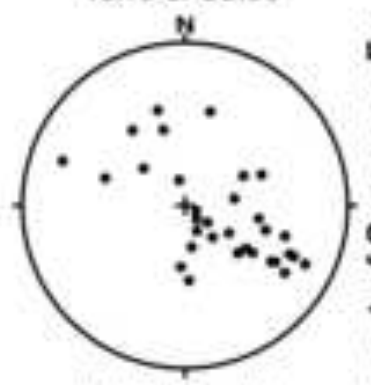

(1) $\mathrm{AP}_{y}, \mathrm{n}=33$

Punta Telegrafo

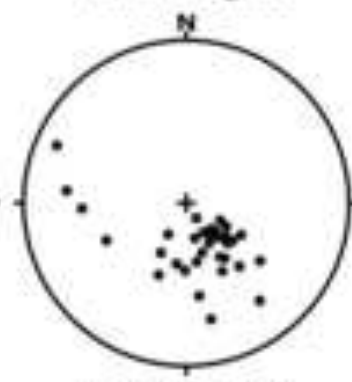

(1) $\mathrm{AP}_{2} \approx, \mathrm{n}=33$

Pisciotta Marina

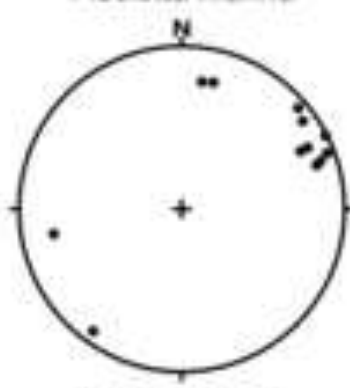

(m) $A_{,}, n=12$

Torre di Caleo

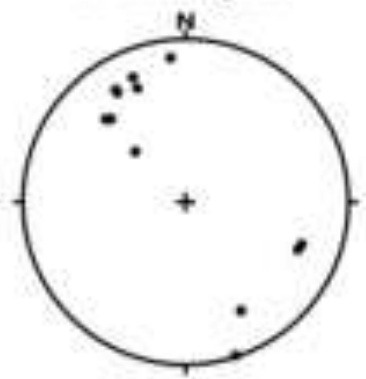

(n) $\mathrm{AP}_{5}, \mathrm{n}=11$

Torre di Caleo

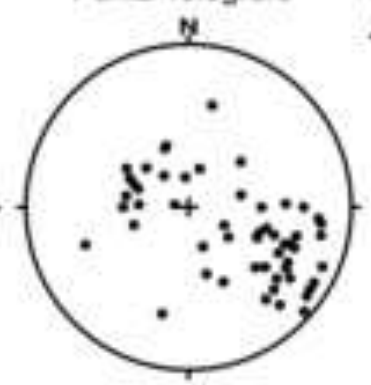

(o) $S_{i}^{*}, n=54$

Punta Telegrafo

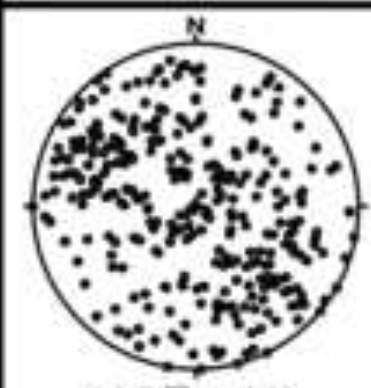

(p) $\mathrm{S}^{4}, \mathrm{n}=353$

Pisciotta-Ascea

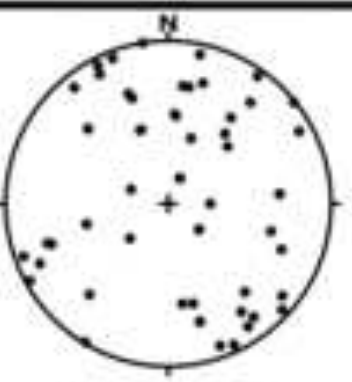

(q) $A_{1}{ }^{n C}, n=59$

Pisciotta-Ascea

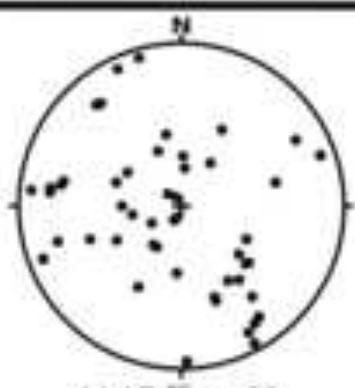

(r) $\mathrm{AP}_{4}{ }^{2}, n=59$

Pisciotta-Ascea

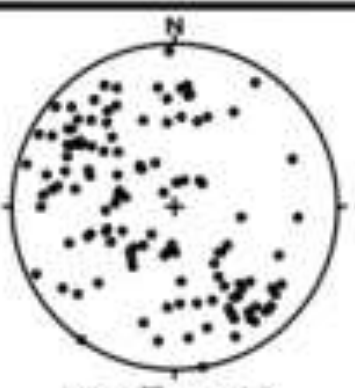

(s) $S, n, n=127$

Pisciotta-Ascea

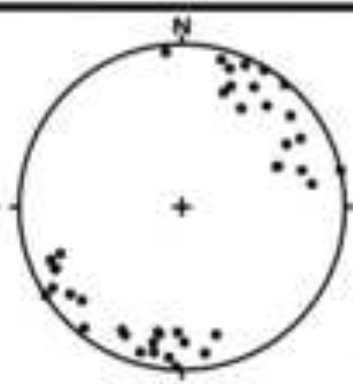

(t) $A_{2}=, n=41$

Pisciotta-Ascea

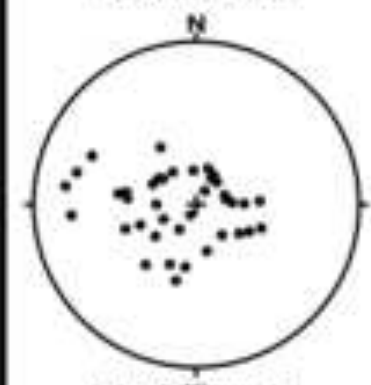

(u) $\mathrm{AP}_{x}{ }^{\mathrm{s}}, n=41$

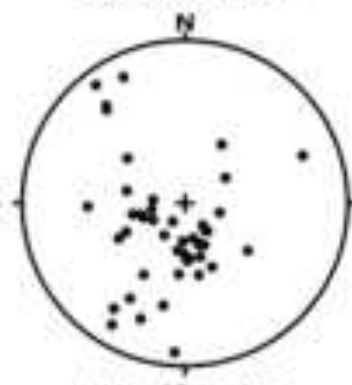

(v) $S_{i}^{N 0}, n=46$

Pisciotta-Asces

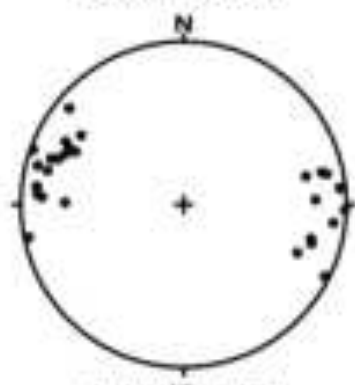

(w) $A^{* 4}, n=35$

Pisciotta-Ascea

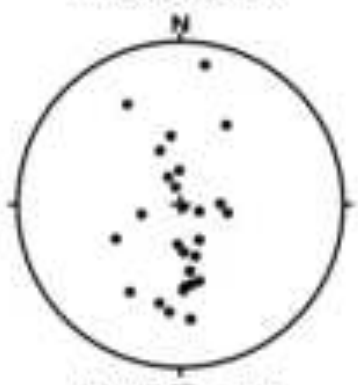

(x) $A P_{3}, n=35$

Pisciotta-Ascea 

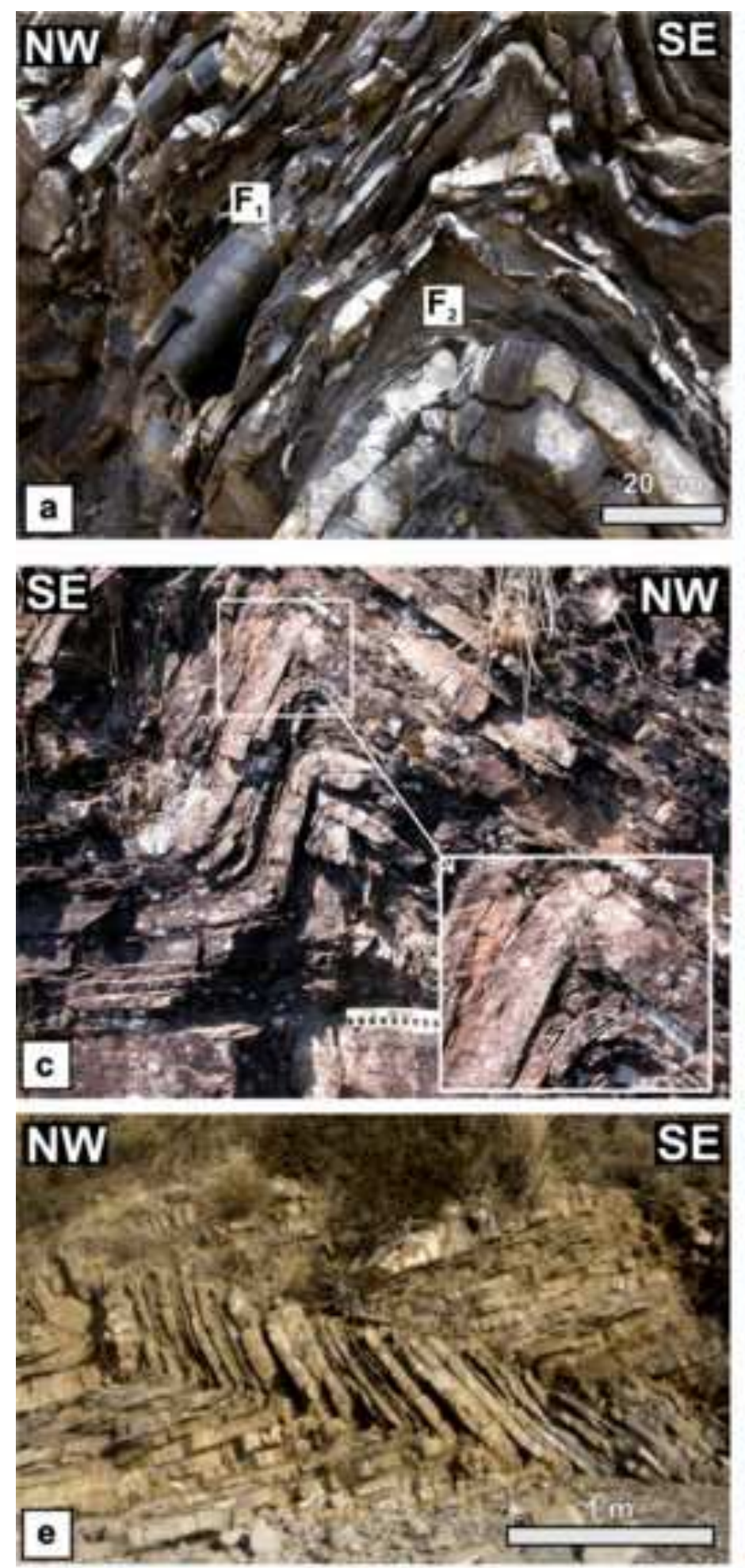

SE
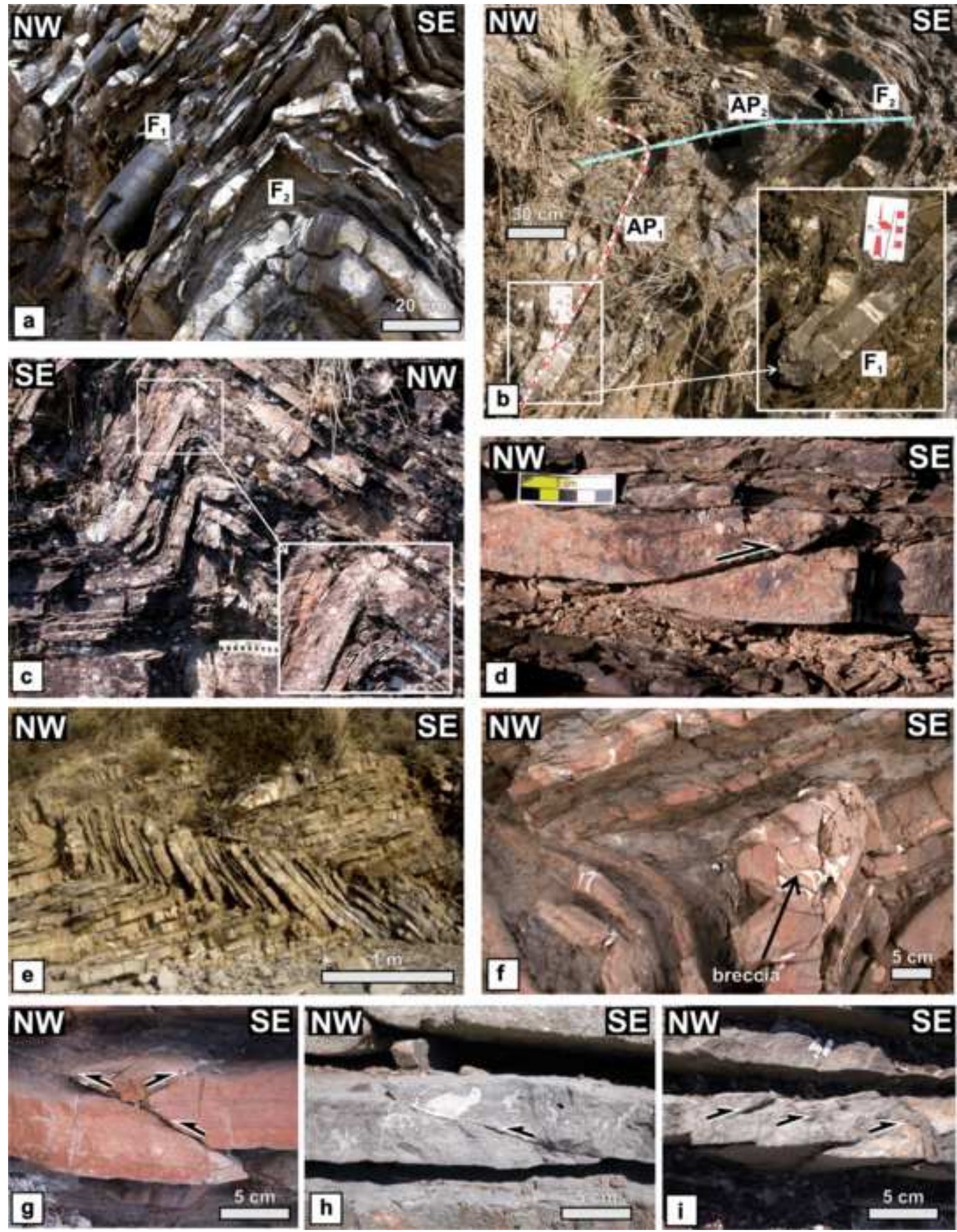

SE

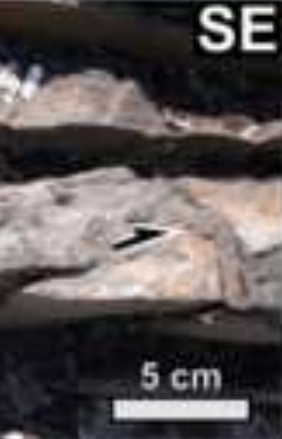




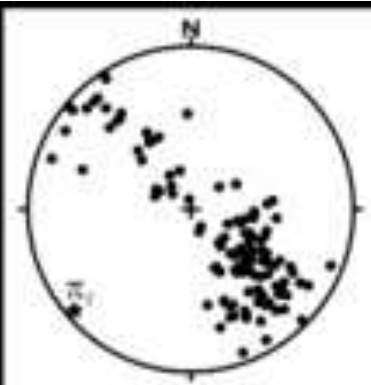

(a) $S_{i}^{* 0}, n=125$

Cannicchio

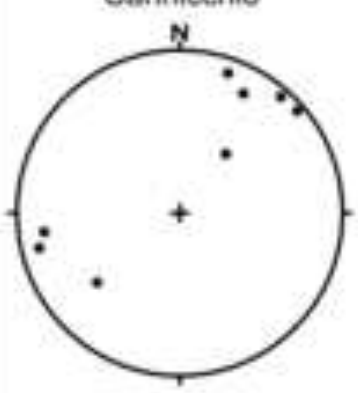

(f) $\mathrm{A}^{\mathrm{ca}}, \mathrm{n}=\mathrm{8}$

Omignano

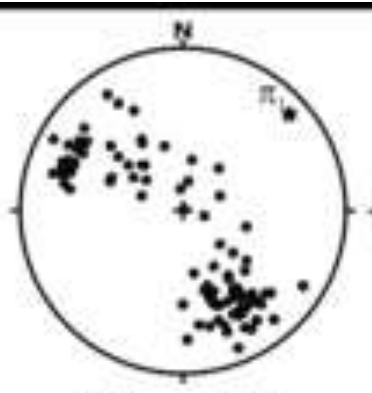

(b) $S_{*}, n=111$

Omignano

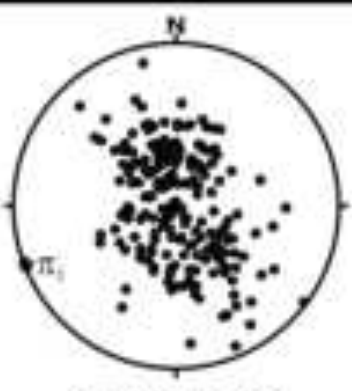

(c) $\mathrm{S}_{6}^{\text {ta }}, \mathrm{n}=219$

Salento-Orria

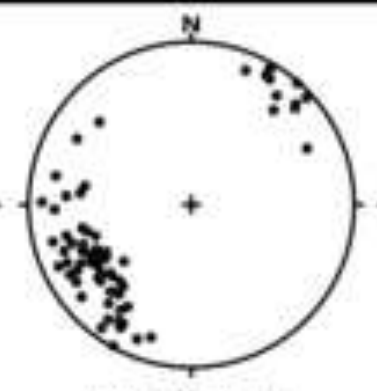

(d) $A_{4}{ }^{\infty 0}, n=74$

Cannicchio

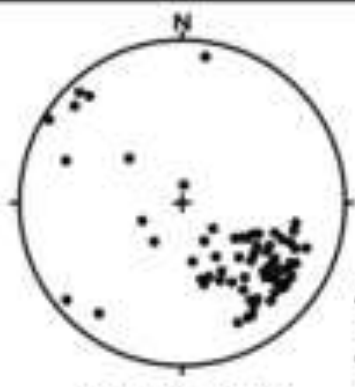

(e) AP, $n=72$ Cannicchio

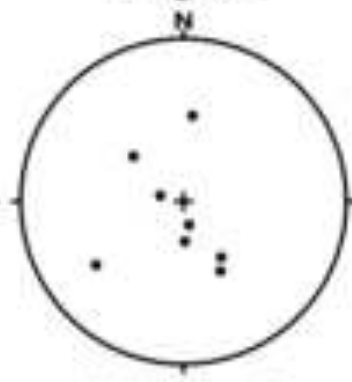

(g) $A P_{1}, n=8$ Onignano

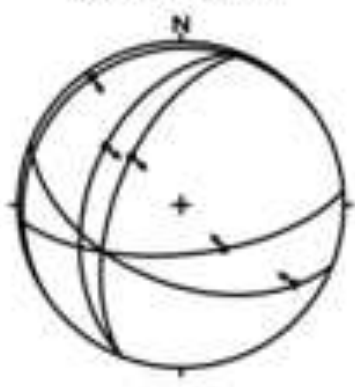

(h) reverse faults, $n=5$ Cannicchio

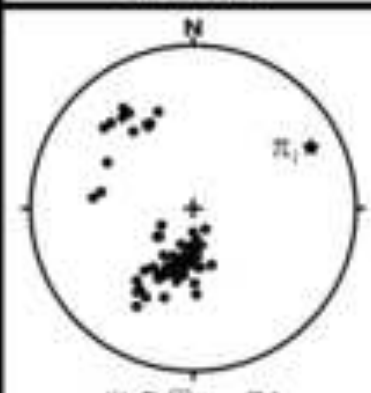

(i) $S_{*}^{\infty}, n=74$

Ogliastro-Agnone

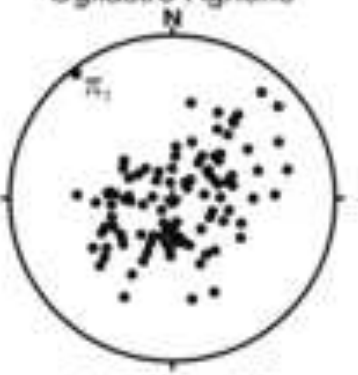

(n) $\mathrm{S}^{\mathrm{ce}}, \mathrm{n=103}$

Gioi-Cardile

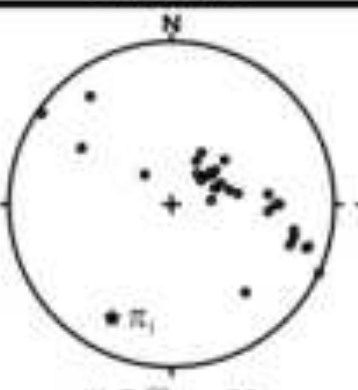

(i) $S_{a}^{\infty}, n=30$

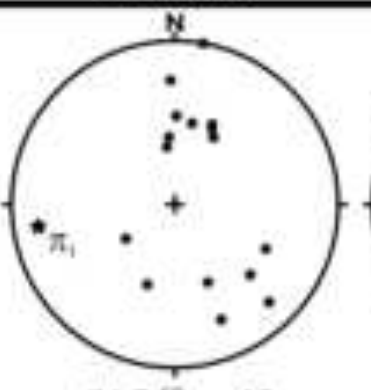

(k) $S,{ }^{, 0}, n=16$

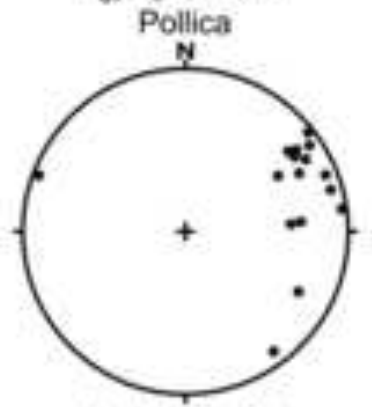

(o) $A_{1}, n=16$ Ogliastro-Agnone

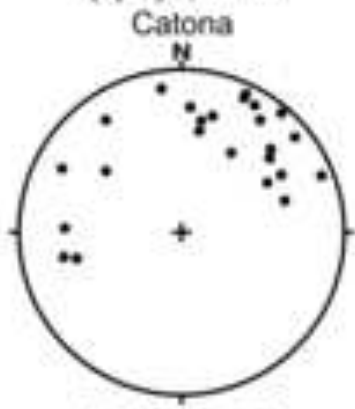

(p) A, ${ }^{\infty 4}, n=24$ Omignano

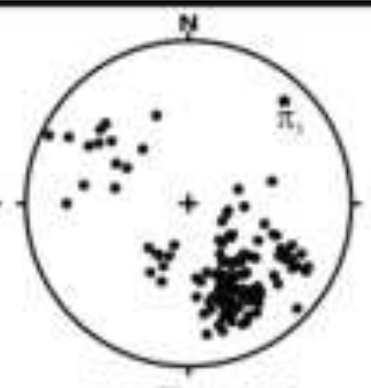

(i) $S_{4}{ }^{c u}, n=129$

Omignano

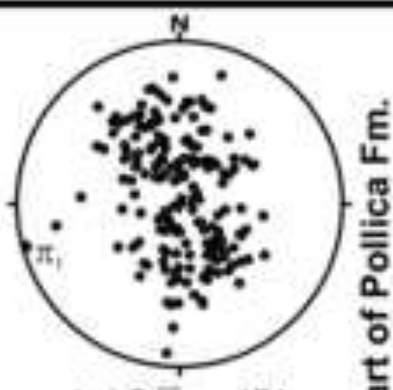

(m) $S_{1}, n=174$
늠

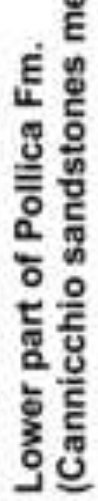

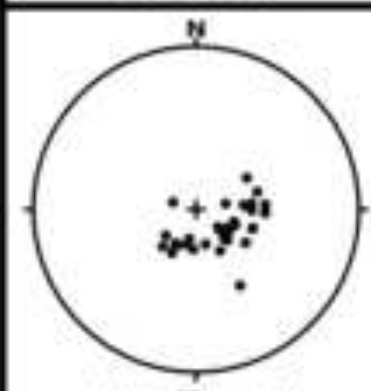

(s) $S, n=34$ Omignano

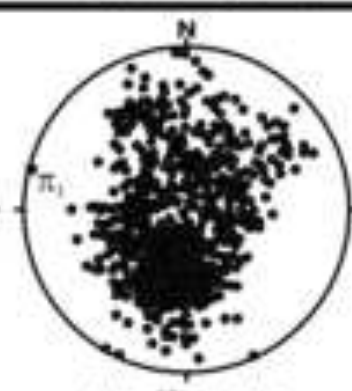

(t) $S, n=546$ Orria-Piano Vetrale

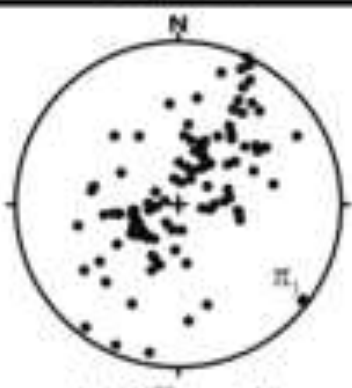

(u) $\mathrm{S}, \mathrm{n}=100$ Giol-Cardile

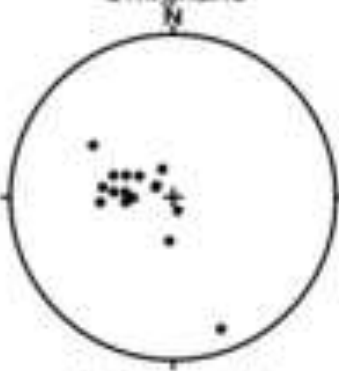

(q) $A P^{\text {ch }}, n=16$ Ogliastro-Agnone

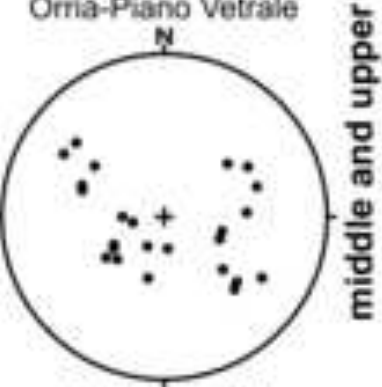

(r) $A P, n=24$ Omignano

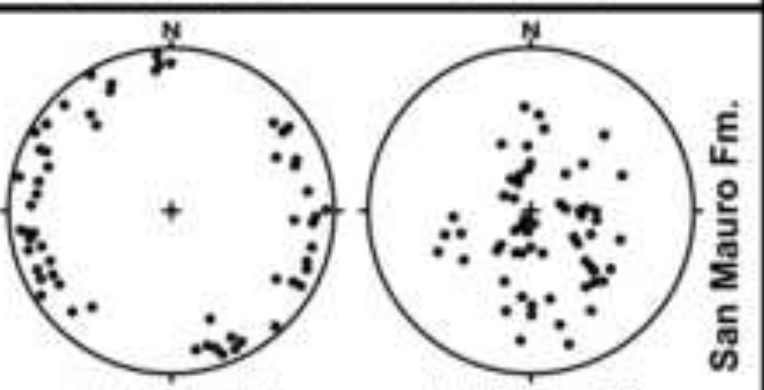

(v) $A, n=62$ Orria-Stio-Salento (w) $\mathrm{AP}_{1}{ }^{\mathrm{n}}, n=62$

Orria-Stio-Salento 


Wedge top-basins



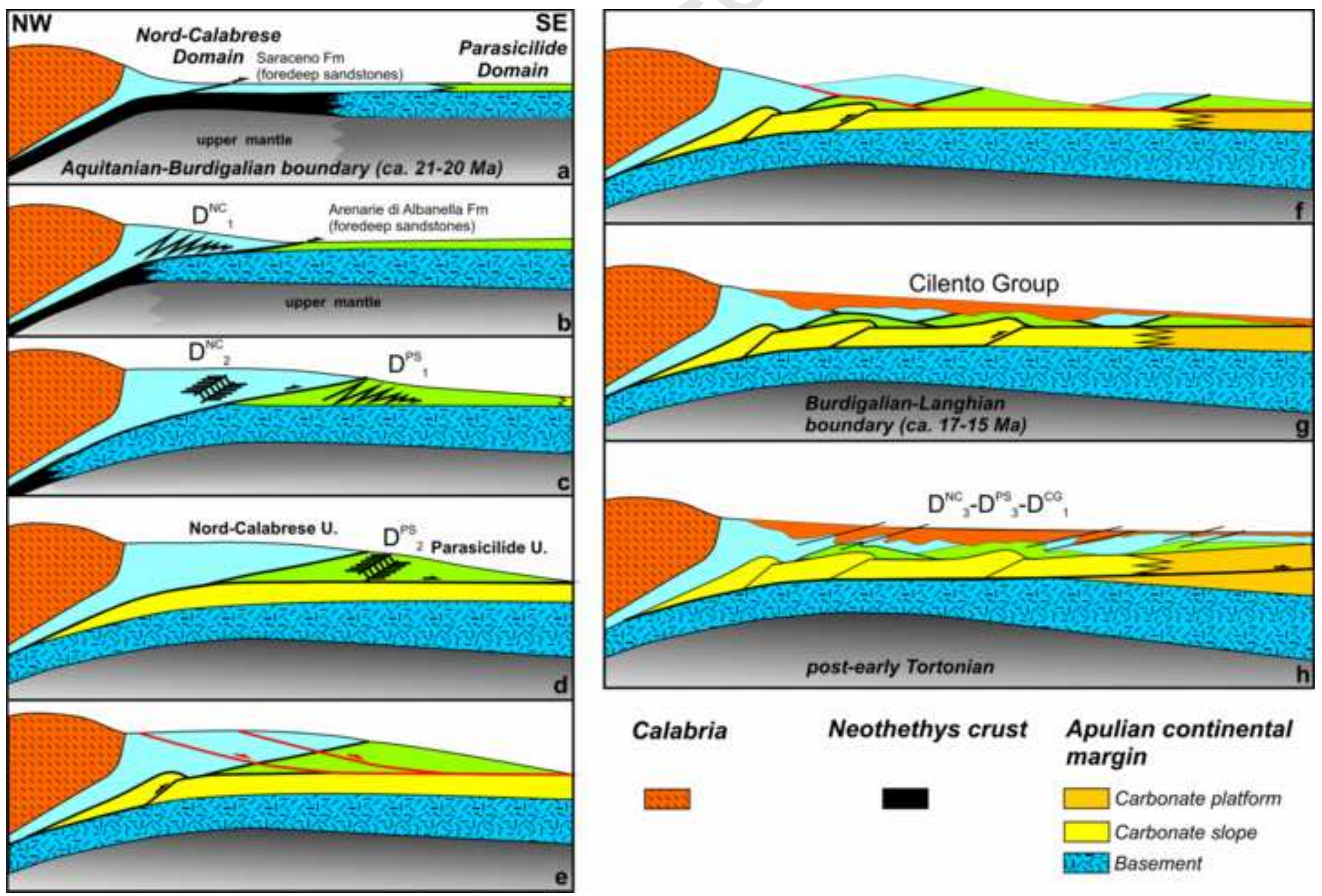

Calabria

四圆
Neothethys crust

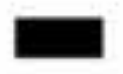

Apulian continental margin

$\square$ Carbonate platform

$\square$ Carbonate slope

[.3B Basement

Page 37 of 38 


\begin{tabular}{|c|c|c|c|c|}
\hline & \multicolumn{3}{|c|}{ Burdigalian } & early \\
\cline { 2 - 4 } & $\mathrm{I}$ & $\mathrm{II}$ & $\mathrm{III}$ & \\
\hline Cortonian
\end{tabular}

